\title{
Fishing for scavengers: An integrated study to amphipod (Crustacea: Lysianassoidea) diversity of Potter Cove (South Shetland Islands, Antarctica)
}

\author{
Meike Anna Seefeldt ${ }^{1,2}$, Alexander M. Weigand ${ }^{3,4}$, Charlotte Havermans ${ }^{2,5}$, Eugenia Moreira ${ }^{6}$, \\ Christoph Held ${ }^{2}$
}

1 Department of Animal Ecology, Evolution and Biodiversity, Faculty of Biology and Biotechnology, Ruhr-University Bochum, Bochum, Germany

2 Functional Ecology Section, Alfred Wegener Institute Helmholtz Centre for Polar and Marine Research, Bremerhaven, Germany

3 Aquatic Ecosystem Research, University of Duisburg-Essen, Essen, Germany

4 Centre for Water and Environmental Research, University of Duisburg-Essen, Essen, Germany 5 Marine Zoology, Bremen Marine Ecology (BreMarE), University of Bremen, Germany 6 Instituto Antártico Argentino, Buenos Aires, Argentina

*corresponding author: meike.seefeldt@rub.de

\begin{abstract}
Amphipoda from the superfamily Lysianassoidea Dana, 1849 play an important role in Southern Ocean benthic food webs due to their high biomass, abundance and predominantly scavenging mode of feeding. Our knowledge on the lysianassoid fauna, even in well-studied areas of the Western Antarctic Peninsula, is incomplete. Here we report the findings of an integrated study of lysianassoid amphipods of Potter Cove, King George Island/ Isla 25 de Mayo (KGI), combining morphological and molecular species identification (COI barcoding) methods, investigating more than 41,000 specimens from baited traps. For comparison, 2039 specimens from the adjacent Marian Cove were analysed. Ten lysianassoid species were recorded in the deeper outer Potter Cove, whereas the inner cove $(<50 \mathrm{~m})$ was dominated by a single species, Cheirimedon femoratus Pfeffer, 1888 (99.44\% relative abundance). It is hypothesized that the impoverished lysianassoid fauna inside the meltwater-influenced inner cove represents a 1model for future conditions along the Western Antarctic Peninsula under conditions of increased glacial melting.
\end{abstract}


Abyssorchomene charcoti (Chevreux, 1912) and Orchomenella pinguides Walker, 1903 were recorded in KGI waters for the first time. Furthermore, one new lysianassoid amphipod species of the genus Orchomenella Sars, 1890 is described: Orchomenella infinita sp. n. Seefeldt, 2017. First-time DNA barcode data was established for Cheirimedon femoratus, Hippomedon kergueleni Miers, 1875, Orchomenella rotundifrons K.H. Barnard, 1932 and Orchomenella infinita sp. n.

\section{Keywords}

Biodiversity inventory; DNA barcoding; Lysianassidae; Taxonomy; New species; Southern Ocean; Glacier retreat

This article is registered in ZooBank under urn:lsid:zoobank.org: pub: 829D1ED2-936D-4121-9D2E3C65D4BCE63A

\section{Acknowledgments}

The authors thank the DNA/IAA and the staff of Carlini station 2014/2015 and 2015/2016 for logistics and support. We would like to thank particularly E. Barrera-Oro, O. Gonzáles, C. Bellisio, J. Movilla, L. Torre, J. Piscicelli, G. Alurralde for help in the field and lab. A sincere gratitude is owed to D. Abele for supporting this project. Furthermore, we want to thank R. Tollrian for his encouragement and the provision of technical equipment, M. Schweinsberg and K. Lampert for assistance in the laboratories at RUB. We are grateful to K. Jerosch for generating the maps. We thank A. Feuring for her help in sorting some samples. We greatly acknowledge the constructive comments of two anonymous reviewers. The first author particularly expresses her deep gratitude to H. Kiepe and team for support and logistics.

This study was funded by the German Research Foundation (DFG) with the project TO 171/9-1, HE 3391/7-1 and C. Havermans with the project HA 7627/1-1 funded through the Priority Programme 1158 on Antarctic Research.

The present manuscript also presents an outcome of the EU research network IMCONet funded by the Marie Curie Action International Research Staff Exchange Scheme (FP7 IRSES, Action No. 319718). 


\section{Introduction}

Understanding the eco-functional role of species, communities, and ecosystems are prerequisites for biodiversity conservation. This is particularly true for remote and vulnerable environments, such as the Western Antarctic Peninsula (WAP) region. The WAP region belongs to one of the most rapidly changing environments worldwide caused, inter alia, by the increase of air temperatures and its consequences such as rapid glacier retreats and loss of sea ice (see e.g. Gutt 2016; Turner et al. 2005, 2014). Thus, an accurate assessment of species diversity and community composition is needed. The Antarctic marine biota is characterized by a surprisingly high species richness and a high rate of species endemism, which is generally assumed to be a consequence of the isolating effect of the Antarctic Circumpolar Current (Arntz et al. 1997; Brandt 1999; Poulin 2002; Clarke and Johnston 2003) as well as the effect of glacial and interglacial periods, subsequently isolating and reconnecting shelf populations and those on the surrounding slope and in the deep sea (Clarke and Crame 1989; Allcock and Strugnell 2012). With over 900 species recorded in the Southern Ocean and more than 500 species in the Antarctic region, amphipods represent the dominant taxon among peracarid crustaceans (De Broyer et al. 2007). The superfamily Lysianassoidea is one of the key amphipod taxa with respect to species richness, abundance and ecological importance in the region. Many lysianassoid species are scavengers, known to gather in enormous numbers on large carcasses which they are able to devour within hours or days (e.g. Slattery and Oliver 1986). At the same time, they function as an important food source for higher taxa particularly fish, birds and mammals (Dauby et al. 2001; De Broyer et al. 2004; Moreira 2015; Moreira et al. 2016). The amphipod scavenger fauna can be easily sampled and studied by the deployment of baited traps, an approach which has a century-long history of investigations on scavenging amphipods of the world-wide oceans from the shelf to the deep sea (e.g. Arntz and Gutt, 1997; De Broyer et al. 2004; Horton et al. 2013; Hurley, 1965; Ingólfsson and Agnarsson, 1999; Legeżyńska et al. 2000; Presler, 1986; Walker, 1907; Wickins, 1982). These trap deployments, with which huge umbers of specimens could be sampled and new species described, served investigations on marine biodiversity in the WAP area from the very beginning of Antarctic research to nowadays (for an overview see De Broyer et al. 2011).

King George Island (KGI) is the largest island of the South Shetland Islands and has three bays: King George Bay, Admiralty Bay and Maxwell Bay. The latter two bays consist of many fjord-like inlets. Amongst others, the Argentinean scientific station Carlini (formerly known as Jubany), where also the Argentinean-German Dallmann Laboratory is situated, is located in Potter Cove, Maxwell Bay. For the last three decades, international research has focused on environmental changes caused by the climate-driven retreat of the 
Fourcade Glacier, increase of water temperature and its consequences, including freshwater runoff, high sedimentation and benthic community shifts (e.g. Wiencke et al. 1998, 2008; Rückamp et al. 2011, Quartino et al. 2013; Pasotti et al. 2014; Schloss et al. 2014; Falk et al. 2015, Sahade et al. 2015; Fuentes et al. 2016).

Extensive research data already exists for the amphipod fauna of Admiralty Bay (e.g. Jażdżewski 1981; Presler 1986; Jażdżewski et al. 1991, 1992, 1995, 2001; Chapelle and Peck 1995; Jażdżewski and Konopacka 1999; Jażdżewska 2011), primarily acquired by scientists from the Polish Arctowski station and the Brazilian Comandante Ferraz Antarctic Station. The Admiralty Bay Benthos Diversity Database web page (ABBED, www.abbed.uni.lodz.pl; Siciński et al. 2011) lists 172 amphipod species, of which 29 belong to the superfamily Lysianassoidea (pers. communication A. Jażdżewska), representing six families. Kim et al. (2014) published the first amphipod checklist of the sublittoral zone of Marian Cove, one of several fjord-like inlets situated in Maxwell Bay. The authors listed 22 amphipod species belonging to twelve families, including two lysianassid species. In the studies of Rauschert (1988, 1989, 1990, 1991), focussing on the Fildes Peninsula shore, the south western part of KGI, and the Fildes Strait, amphipod data has been published, listing 103 species. However, the presence of some of these amphipod species is questionable and needs reevaluation. For example, Rauschert (1990, 1991) reported the occurrence of Tryphosella cf. sarsi Bonnier, 1893, a lysianassid species previously only known from the North Sea and North Atlantic, and Casaux et al. (1990) as well as Momo et al. (1998) reported the occurrence of the deep-sea species Valettia coheres Stebbing, 1888 (moved to the familiy Valettidae by Thurston, 1989) in Potter Cove.

Due to conservative and often slight morphological diagnostic characteristics, species identification of lysianassoid amphipods is error-prone. At the same time, accurate species identifications are paramount for a multitude of downstream analyses dealing with or relying on ecological and biodiversity data. Here we report the results of the first integrative taxonomic study of lysianassoid amphipods of Potter Cove (KGI, Antarctica), applying morphological and molecular data to provide up-to-date species delimitation hypotheses and examination of the taxonomy of an important group in the Potter Cove scavenging guild. Furthermore, the new lysianassid species Orchomenella infinita sp. n. Seefeldt, 2017 is described and species diversity and taxonomic composition compared to the lysianassoid amphipod fauna of the adjacent Maxwell Bay and Admiralty Bay. 


\section{Material \& Methods}

\section{Study area and sampling}

The study was conducted at the Argentinean-German Dallmann Laboratory at the Argentinean scientific research station Carlini situated at Potter Cove, Maxwell Bay, on King George Island. Potter Cove is divided into an outer and inner cove defined by an underwater sill at $30 \mathrm{~m}$ depth. While the outer cove is characterized by a depth up to $200 \mathrm{~m}$ and mainly rocky hard substrate, the inner cove has a maximal depth of $50 \mathrm{~m}$ and is dominated by soft sediments. Further detailed hydrographical and biological features of the cove can be found in Klöser et al. (1994), Wiencke et al. (1998) and Wölfl et al. (2014).

Scavenging amphipods were sampled using traps made of a perspex hollow cylinder $(50 \mathrm{~cm}$ length, $10 \mathrm{~cm}$ diameter, $5 \mathrm{~mm}$ wall thickness) closed on one side and equipped with a funnel-shaped entrance on the other side ( $1 \mathrm{~cm}$ diameter entrance). The traps were baited with accessable, either entire but dissected or pieces of dead Antarctic fish (Notothenioidei: Notothenia rossii Richardson, 1844; N. coriiceps Richardson, 1844; Chaenocephalus aceratus (Lönnberg, 1906)) of variable weights (100-250 g). To avoid unnecessarily killings of fish specimens as bait, and the given opportunity of a reutilisation of fish specimens from another project on-site, the variation of bait species and quantity was depending on their availability. Traps were deployed from a zodiac boat in the Antarctic spring/summer season 2014/2015 and summer season 2016 at depths between 12 and $43 \mathrm{~m}$ depth, positioned at $1 \mathrm{~m}$ above the bottom (Fig. 1, Table 1). Due to unpredictable weather conditions, which limited the ability of trap recovery, the duration of deployment varied from 44 hours to 65 hours with one extreme deviation of 8 days (Table 1; Station ID 02). A comparable number of traps were deployed in the outer and inner cove (11 and 9, respectively). In addition, four baited traps were deployed in Marian Cove at depths between 20 and $40 \mathrm{~m}$ to serve as a comparison with the recent study of Kim et al. (2014).

\section{Identification and species description}

Specimens were identified morphologically using original species descriptions, taxonomic revisions and redescriptions including Barnard K.H. (1932), Bellan-Santini (1972), d'Udekem d'Acoz and Havermans (2012). Sorting, identification and counting were performed using the stereomicroscopes Olympus SZH10 and ZEISS Stemi. Prior to preservation, selected animals were photographed using an Olympus DP21 camera attached to the stereomicroscope Olympus SZ-DF or with the digital camera Olympus OM-D EM-5 using a $60 \mathrm{~mm}$ macro lens. In particular cases, preserved specimens were pictured using the camera Olympus SDF attached to the stereomicroscope Olympus SZX16. All specimens were fixed and preserved predominantly in $96 \%$ undenatured 
ethanol. For species description, appendages (except uropods) of the left side of the body of the female holotype specimen were dissected and temporary glycerine slides of appendages were prepared. As some characters of the holotype specimen were not in a sufficient condition, complementary drawings of the pleon and antenna 1 as well as a description of epimerons of a male paratype specimen (ZMB 30508) were additionally prepared. The pencil drawings were produced using Olympus BX40, Olympus SZH10 and LEICA MZ16 camera lucidas attached. Drawings were digitized using Adobe Illustrator CS4 following the instructions and settings of Coleman $(2003,2009)$ using WACOM Intuos tablets 3 and 5.

The terminology for setae and spines used in the species description follows the suggestions of d'Udekem d'Acoz (2010) and Krapp-Schickel (2011) where spines are defined as stout, articulated, inflexible structures and setae being slender, flexible and articulated structures.

The following abbreviations are used in figures 8-10: A1-2: antennae 1-2; Mx1-2: maxillae 1-2; MD: mandible; Mxp: maxilliped; Gn1-2: gnathopods 1-2; P3-7: pereopods 3-7; Cx: coxa; Ba: basis; Ca: carpus; Pr: propodus; D: dactylus; Ep1-3: epimerons 1-3; Uros1-3: urosomites 1-3; U1-3: uropods 1-3

\section{DNA isolation, PCR and sequence processing}

Specimens from Potter Cove used for molecular analyses were sorted to morphotypes and are registered and deposited at the Museum für Naturkunde, Leibnitz-Institut für Evolutions- und Biodiversitätsforschung, Berlin, Germany (ZMB, Table 2). For DNA isolation, three pairs of pleopods and in cases of small specimens (approx. 5 $\mathrm{mm}-1 \mathrm{~cm}$ ) also pereopods from one side of the body were used to ensure a sufficient amount of DNA. Extraction followed the Blood \& Tissue DNeasy Kit (Qiagen) manufacturer's protocol. Only $100 \mu \mathrm{L}$ TE buffer were used for sample elution. PCR-amplification of the $\mathrm{COI}$ barcoding region (i.e. Folmer fragment of the Cytochrome C Oxidase subunit I gene) was carried out by using the modified Folmer-primers LCO1490-JJ (5'CHACWAAYCATAAAGATATYGG-3') and HCO2198-JJ (5'-AWACTTCVGGRTGVCCAAARAATCA-3') of Astrin and Stüben (2008). The premix for polymerase chain reaction consisted of a total volume of $25 \mu \mathrm{L}$ containing $2.5 \mu \mathrm{L}$ 10X PCR buffer, $2.5 \mu \mathrm{L}$ dNTPs $(2 \mathrm{mM}), 0.125 \mu \mathrm{L}$ of each primer $(100 \mathrm{pmol} / \mu \mathrm{L}), 0.125 \mu \mathrm{L}$ of HotMaster Taq DNA Polymerase (5 U/ $\mu \mathrm{L}, 5$ PRIME GmbH, Hamburg, Germany), $2 \mu \mathrm{L}$ or $5 \mu \mathrm{L}$ of template DNA and replenished with $17.625 \mu \mathrm{L}$ or $14.625 \mu \mathrm{L}$ molecular grade water. PCR settings for $C O 1$ amplification were: initial denaturation at $94{ }^{\circ} \mathrm{C}$ for $120 \mathrm{~s} ; 36$ cycles of denaturation at $94{ }^{\circ} \mathrm{C}$ for $40 \mathrm{~s}$, annealing at $52.5{ }^{\circ} \mathrm{C}$ for 40s, extension at $65{ }^{\circ} \mathrm{C}$ for $120 \mathrm{~s}$; final extension at $65^{\circ} \mathrm{C}$ for $8 \mathrm{~min}$. The PCR products were sequenced with terminal primers using the sequencing services of EUROFINS (Germany), and GATC Biotech AG (Konstanz, 
Germany). Sequence chromatograms were edited and assembled in Geneious 5.6.7 (Kearse et al. 2012). The CO1 alignment was constructed using the Geneious-plugin MAFFT v7.017 under the G-INS-i option recommended for sequences with global homology (Katoh et al. 2002).

\section{Genetic diversity}

Since two pseudo-cryptic lineages of Waldeckia obesa (Chevreux, 1905) are known (Havermans 2012), we included as references a total of ten sequences of Waldeckia obesa cluster 'A' and 'B' sensu Havermans (2012) in the analyses (Table 2). Mean genetic diversity for each species (intraspecific) and between species (interspecific) were calculated in MEGA 6.06 (Tamura et al. 2013) under the Kimura-2 parameter (K2P) substitution model generally used for DNA barcode data and the pairwise deletion option. A trimmed $544 \mathrm{bp}$ CO1 alignment was used, as some sequences demonstrated missing data at either the 5' or 3' end. In the final alignment, all except two sequences were of full length, i.e. MT002Pp1001 (70 bp shorter at 5' end) and MT002Oro013 (6 bp shorter at 3' end). A CO1 neighbour-joining tree was generated in MEGA 6.06 using the K2P substitution model including transitions and transversions, 1000 bootstrap replicates and midpoint rooting. All DNA barcodes are cross-checked against the Barcode of Life Data System (BOLD, http://www.barcodinglife.org). DNA barcode data (i.e. sequences and additional information) of all genetically analysed specimens are stored and publically available in the project LYAPO (Lysianassoid Amphipods of Potter Cove) of the Barcode of Life Data System (BOLD, Ratnasingham and Hebert 2007) as well as in the public database of the National Centre for Biotechnology Information (NCBI).

\section{Results}

\section{Species composition and morphological diversity}

A total of more than 43,900 lysianassoid amphipod specimens (suppl. material 1) were sampled in 24 deployed baited traps. In the 20 analysed traps deployed throughout Potter Cove, 41,898 specimens of eleven distinct lysianassoid morphospecies were recorded, of which nine could be identified as known species (Fig. 2, Fig. 3). The two species Abyssorchomene charcoti (Chevreux, 1912) and Orchomenella pinguides Walker, 1903 were recorded in KGI waters for the first time. One new species - Orchomenella infinita sp. n. - is described herein. Individuals of Hippomedon kergueleni (Miers, 1875) demonstrated different colour patterns (morphotypes) 
indicating that specimens may belong to two distinct species. While some H. kergueleni specimens had an offwhite body colour (white morphotype), others were of a darker yellow colour with reddish pigmentation dorsally on pereonites and pleonites as well as on peduncle of antenna 1 and dorsal parts of the coxal plates (red morphotype) (Fig. 2a, b). This colour pattern was consistent for both sexes.

Some specimens of Orchomenella rotundifrons K.H. Barnard, 1932 showed morphological variations, sharing some character states with Orchomenella denticulata Rauschert, 1995, i.e. a serrated posterior margin of epimeral plate 3 and intermediate forms of dorsal humps and carinations on urosomite 1 . For this reason some individuals were determined as $O$. cf. rotundifrons, designated as 'Oxx' (Table 2) and included in the barcoding analyses in order to clarify their taxonomic status.

Two lineages (cluster 'A', and 'B') of Waldeckia obesa were revealed by Havermans (2012). Our morphological reexamination of specimens from these lineages were compared and both comparisons with the original description and redescription of $W$. obesa in the publications of Chevreux $(1905,1906)$ as well as the recent revision of the genus Waldeckia by Lowry and Kilgallen (2014), enabled us to identify morphological evidence for considering the clusters as two distinct species. While the nominal W. obesa (cluster 'A', sensu Havermans 2012) has a labrum with a separate epistome and upper lip, a relatively short, acute hump on urosomite 1 and the posterolateral corner of epimeron 3 sickle-shaped and hooked, specimens belonging to cluster ' $\mathrm{B}$ ' bear a longer, more curved hump on urosomite 1 with a flattened notch before ending into a small tooth. The labrum, epistome and upper lip are fused. Since specimens from cluster 'B' do not resemble any other described species of the genus Waldeckia, this is here confirmed as new to science and will be described elsewhere. Finally, all morphospecies, but not morphotypes, for which $\mathrm{COI}$ sequence data were obtained, were also supported as distinct taxa by molecular data (Fig. 4).

\section{Genetic diversity and DNA barcode data}

CO1 sequences (i.e. DNA barcodes) were generated for all species except Orchomenella pinguides and Pseudorchomene coatsi (Tab.2). The total molecular dataset comprised 79 sequences, of which 69 have been newly generated from Potter Cove. Those comprise eight morphospecies including a red coloured (11 specimens) and a white coloured (8 specimens) morphotype of Hippomedon kergueleni Miers, 1875. The dataset was complemented with two sequences of Waldeckia obesa cluster 'A' and eight sequences of the pseudocryptic and co-occurring lineage cluster 'B' sensu Havermans (2012) from different localities of the Southern Ocean. 
Existing $\mathrm{CO}$ sequences data in BOLD is augmented for $P$. rossi (Barcode Index Number [BIN]: BOLD:AAG7165, identified in BOLD as Abyssorchomene rossi), P. plebs (BOLD:AAL8109), A. charcoti (BOLD:AAN0316) and W. obesa. Our sequences of $W$. obesa from Potter Cove demonstrate only max. 86.6\% identity with two sequences taxonomically designated as W. obesa in BOLD. Since they are not yet publically available, no further information could be retrieved. However, 100\% and $99.1 \%$ sequence identity is achieved with two single-specimen BINs (BOLD:AAL8112) and (BOLD:AAL8113) currently identified only as 'Amphipoda' in BOLD. These two specimens originate from Moon Bay (Livingston Island, South Shetland Islands). For H. kergueleni, O. rotundifrons, Cheirimedon femoratus and O. infinita sp. n. we establish first-time DNA barcode data.

Intraspecific genetic diversity is generally low (Table 3, Fig. 5), with the highest value obsesrved for W. obesa cluster 'A' (2.8\%). Interspecific genetic diversity ranges from $10.2 \%$ (A. charcoti / O. rotundifrons) to $40.1 \%$ (Waldeckia obesa cluster 'B' / O. infinita sp. n.). Specimens of H. kergueleni with red and white morphotypes possess identical $\mathrm{COI}$ sequences, as do all analysed specimens of $O$. rotundifrons bearing morphological variations as indicated earlier (Fig. 4).

\section{Relative abundances}

The analysis of the sampled amphipod specimens demonstrated clear patterns in distribution and species composition. The omnivore lysianassid Cheirimedon femoratus (Pfeffer, 1888) represented $79.81 \%$ of all collected specimens and was the most abundant species in Potter Cove (Table 4, Fig. 6) followed by Hippomedon kergueleni (Miers, 1875) (13.86\%), Orchomenella rotundifrons K.H. Barnard, 1932 (5.04\%) and Waldeckia obesa (Chevreux, 1905) (1.25\%). Orchomenella infinita sp. n., O. pinguides, Pseudorchomene coatsi (Chilton, 1912), Pseudorchomene plebs (Hurley, 1965), Pseudorchomene rossi (Walker, 1903), and Abyssorchomene charcoti contributed only with less than $0.01 \%$ to the total number of specimens sampled in Potter Cove. Considering the relative abundances of lysianassid amphipods in the inner cove only, C. femoratus reached the highest proportion of $99.44 \%$, whereas the other seven trapped species occurred in far lower abundances (Table 4 : from $0.38 \%$ to $<0.01 \%$ ). The highest number of $C$. femoratus individuals per trap $(11,922$ specimens, suppl. material 1) was found at $12 \mathrm{~m}$ depth at approximately $60 \mathrm{~m}$ distance from the glacier. The species composition and relative abundances of the outer cove differed from the inner cove in that besides $C$. femoratus (67.61\%) also H. kergueleni (22.25\%), O. rotundifrons $(8.07 \%)$ and W. obesa $(2.02 \%)$ occurred at higher relative abundances in the outer cove (Table 4). In the adjacent Marian Cove the relative abundances of species differ compared to Potter Cove. Here, 2,039 specimens of four lysianassid species were found: W. obesa 
dominated with $87.00 \%$, while $C$. femoratus $(12.75 \%)$, H. kergueleni $(1.47 \%)$ and $P$. rossi $(0.10 \%)$ occurred in much lower relative abundances.

\section{Taxonomy}

Order. Amphipoda Latreille, 1816

Superfamily. Lysianassoidea Dana, 1849

Family. Lysianassidae Dana, 1849

Subfamily. Tryphosinae Lowry and Stoddart, 1997

Genus. Orchomenella Sars, 1890

Type species. O. minuta Sars, 1890

Species composition. After Horton et al. (2016): Orchomenella aahu (Lowry and Stoddart, 1983); O. acanthurus (Schellenberg, 1931); O. cavimanus (Stebbing, 1888); O. chelipes Walker, 1906; O. chilensis (Heller, 1868); O. decipiens Hurley, 1963; O. denticulata Rauschert, 1995; O. franklini Walker, $1903 ; O$. goniops (Walker, 1906); O. guillei De Broyer, 1985; O. hiata (Andres, 1983); O. holmesi Hurley, $1963 ; O$. hureaui (De Broyer, 1973); O. japonica Gurjanova, 1962; O. kryptopinguides (Andres, 1983); O. lepidula Gurjanova, 1962; O. littoralis Nagata, 1965; O. macrophthalma (Birstein and Vinogradov, 1962; O. minuta (Krøyer, 1846); O. obtusa (G.O. Sars, 1891); O. pacifica Gurjanova, 1938; O. perdido Lowry and Stoddart, 1997; O. pinguides Walker, 1903; O. pinguis (Boeck, 1861); O. rotundifrons K.H. Barnard, 1932; O. tabasco (J.L. Barnard, 1967); O. thomasi Lowry and Stoddart, 1997; O. ultima (Bellan-Santini, 1972); O. zschaui (Pfeffer, 1888)

Remarks. Currently, 29 species are attributed to the genus Orchomenella Sars, 1890, of which 15 are distributed in the Southern Ocean (De Broyer et al. 2007; Horton et al. 2016). The phylogenetic relationships between many lysianassoid families and genera remain unsolved. Molecular studies revealed the polyphyly of the genera Orchomenella and Abyssorchomene De Broyer, 1984 (Corrigan et al. 2014; Havermans et al. 2010). D’Udekem d'Acoz and Havermans (2012) made a detailed listing on the systematic history of the genus Tryphosa Boeck, 1871 also summarizing the phylogenetic relationship to Orchomenella. Resolution of phylogenetic relationships within the Lysianassoidea is beyond the scope of this paper and therefore our new species is placed in the currently defined genus Orchomenella. However, it should be stated that some morphological differences are apparent between our species and the current diagnosis of Orchomenella. The antenna 1 peduncle article 3 is well-developed and unusually long and the first article of the flagellum is not elongate in O. infinita. 


\section{Orchomenella infinita sp. n. Seefeldt}

(Figs. 3, 7-10; Tables 2-4)

Orchomenella cf. ultima- Jażdżewski et al. 1991:109-110, 112, 115

Orchomenella cf. ultima- Jażdżewski et al. 1995:371

Orchomenella cf. ultima- Jażdżewski et al. 2001:910-917 (eco)

Orchomenella sp.- Barrera-Oro and Piacentino 2007:792

Orchomenella (Orchomenella) cf. ultima-ABBED, www.abbed.uni.lodz.pl; Siciński et al. 2011

Orchomenella cf. ultima- Siciński et al. 2012:359-360, 365

Orchomenella cf. ultima- Kim et al. 2014:106, 108-109, 111, Fig 5 G

Lysianassid sp.- Moreira 2015

Orchomenella sp. n.- Barrera-Oro et al. (in prep.)

Type material. 1 HOLOTYPE female, $5.5 \mathrm{~mm}$. ZMB 30506, dissected preserved in 70\% ethanol (temporarily stored in 1:1 glycerin-ethanol (70\%)), King George Island, Potter Cove, sta.9, 62 ${ }^{\circ} 14^{\prime} 23.43^{\prime}$ S 58 $41^{\prime} 52.3^{\prime \prime} \mathrm{W}$, baited trap, $39 \mathrm{~m}, 16.12 .2014$. Pleopods and right pereopods were used for DNA extractions, specimen ID MT009Oul006; BOLD ID: LYAPO020-16. PARATYPE specimens in 96\% ethanol; BOLD ID LYAPO021-16 (MT002Oul014, ZMB 30507): female, $4 \mathrm{~mm}$, sta. 2, 62॰14'21.5“S 58 $41^{`} 52.5^{\circ} \mathrm{W}$, baited trap, $30 \mathrm{~m}$, 14.11.2014; LYAPO022-16 (MT014Oul001, ZMB 30508): male, 4 mm, sta. 14, 62¹4'23.4”S 58 $41^{\prime} 52.5^{\prime \prime} \mathrm{W}$, baited trap, 40 m, 20.12.2014; MT014Oul003, ZMB 30593: male, 4 mm sta. 14, 62¹4'23.4”S 58 $41^{\prime} 52.5^{\prime \prime} \mathrm{W}$, baited trap, 40 m, 20.12.2014; MT002Oul015, ZMB 30592: female, 5 mm, sta. 2, 62¹4’03.2”S 58³9`17.3”W, baited trap, $30 \mathrm{~m}, 14.11 .2014$.

Type locality. Potter Cove, King George Island, South Shetland Islands, Antarctica (62 ${ }^{\circ} 14$ 'S $\left.58^{\circ} 41^{\prime \prime}\right)$.

Etymology. The epitheton infinita (latin: boundless, unlimited, endless, infinite) refers to the seemingly endless discovery of new species and the never ending chaos within the group of 'orchomenids'. It expresses the opposite to the morphologically most similar species, O. ultima, whose name could be misleadingly interpreted as the last species ever described in that genus.

Diagnosis: Eye blazing red when alive. Antenna 1 peduncle article 3 well-developed, unusually long; first article of flagellum not elongate; article 1 of accessory flagellum not strongly elongate; gnathopod 1 basis slender, palm concave; urosomite 1 no dorsal depression, without carina, keel or hump; somites of pereon and pleon with brownish pigmentation forming transversal striped colour patterns, some merging until dorsal parts of coxae (may vanish in alcohol). 
Description. Based on HOLOTYPE female, ZMB 30506. Body: typical lysianassoid appearance in shape. Head: as broad as long, lateral cephalic lobes convex. Eyes large, somewhat pyriform, well-developed ommatidia, blazing red in living organism, colour is fading when preserved in alcohol. Antenna 1: subequal in length to Antenna 2; primary flagellum 11-articulate, first article not elongate, broader than long; accessory flagellum present, 4- articulated, first article not strongly elongated, 2.5x longer than broad; calceoli absent. Antenna 2: calceoli absent; flagellum 9-articulate. Mouthparts: subquadrate. Labrum (Epistome and upper lip): separate; epistome produced subequally, slightly convex. Mandible: incisor with smooth edge with a small denticle on each side; lacinia mobilis present on the left side, slender peg; molar process oval, ridged and fully triturating; palp 3- articulate, attached proximal, markedly below molar process, article 2 slender (7.3x longer than broad), article 3 slender (4x longer than broad) and bent in a sickle shape. Maxilla 1: inner plate elongate, bearing two stout plumose setae distally, equal in size; outer plate with 11 spines (setal-teeth, ST), (modified 6/5 arrangement), ST1-ST5 stout, ST6-ST7 very stout, ST1 three-cuspidate, ST2 four-cuspidate, ST3 four-cuspidate, ST4; ST5 five-cuspidate; ST6 multicuspidate; ST7 multicuspidate, slightly displaced from ST6, STA-D more slender than ST1-ST7, STA five-cuspidate, STB, four-cuspidate, STC six-cuspidate, STD six-cuspidate, palp distal margin with five cuspidate spines and one antero-distal flag seta. Maxilla 2: inner plate slightly shorter than outer plate; outer plate with long denticulate and simple setae distally; inner plate with long plumose setae. Maxilliped: inner and outer plate well-developed; inner plate narrow, with few plumose setae medially; outer plate reaching halfway along 3rd article of palp, bearing two larger stout, nodular spines distally, several shorter stout, nodular spines along medial margin; palp 4- articulated, dactylus long,well-developed. Gnathopod 1: subchelate; coxa large, shorter than coxa 2, subrectangular, not tapering, anterior and posterior margins almost parallel, anterodorsal margin slightly concave, basis elongate and slender (3.5x longer than broad); ischium short; merus missing/broken, carpus subtriangular, subequal in length to propodus; propodus subrectangular, margins subparallel; palm transverse and concave, minutely serrate bearing two long, stout spines at the posteroventral corner; dactylus stout but simple Gnathopod 2: minutely chelate; coxa large, subrectangular, subequal in size to coxa 3 ; basis elongate, long ( $8 \mathrm{x}$ longer than broad); ischium long (4x longer than broad); posterior margin of merus with several long, simple setae and short brush setae; carpus $2.3 \mathrm{x}$ as long as wide, $2.3 \mathrm{x}$ as long as propodus, posterior margin lobate, from midway to distal end of posterior margin with area of dense, very short setae, anterior distal margin with several longer setae; propodus subquadrate, length $1.6 \mathrm{x}$ breadth, anterodistal with many long setae, posterior margin with long setae; dactylus reaching beyond posterior margin of propodus; palm concave. Pereopod 3: coxa large, subrectangular; basis slender (3x longer than broad); anterior margin of merus convex, posterior margin with a few, long setae. Pereopod 4: coxa 1.5x deeper than 
broad, posteroventral lobe well-developed (1.5x broader than deep), posteroventral corner of lobe rounded; basis slender (3.3x longer than broad), no setae visible; ischium and merus similar to Pereopod 3. Pereopod 5: shorter than pereopod 6 and 7; coxa posteriolobate; basis expanded posteriorly, broadly rounded, posterior margin crenate with one short, simple seta in each notch, anterior margin with several short, cone-shaped spines and one longer spine at the anteroventral corner; merus expanded posteriorly longer than broad; carpus longer than broad; propodus 6x longer than broad bearing spines on the anterior margin, anteroventral and posteroventral corner; dactylus slender and curved. Pereopod 6: coxa distinctly smaller than coxa 5, posteriorlobate; basis longer than pereopod 5 basis, expanded posteriorly, posterior margin crenate with one short, simple seta in each notch, anterior margin with cone-shaped spines from midway until just before anteroventral corner, anteroventral corner with two long, stout setae and two slender setae, posteroventral lobe well-developed; merus longer than broad, posterior margin expanded with two crenations, posteroventral corner produced bearing a cone-shaped spine, anterior margin with one long and one short cone-shaped spine, anteroventral corner with one long seta; carpus longer than broad, posterior margin slightly convex, anterior margin with one large cone-shaped spine; propodus much longer than broad, anterior margin with five cone-shaped spines; dactylus, slender and curved. Pereopod 7: coxa round, small; basis expanded, posterior margin convex, crenate with one short, simple seta in each notch, anterior margin with cone-shaped spine from midway until just before anteroventral corner, anteroventral corner with one stout spine, posteroventral lobe well-developed; ischium missing/broken; merus longer than broad, expanded, anterior margin straight, posterior margin convex, with one crenation bearing one cone-shaped spine, posteroventral corner with one stout spine, anteroventral corner with one stout spine; carpus longer than broad, anteroventral corner with spines, posteroventral corner with setae; propodus 5.7x longer than broad, slender anterior margin crenate with stout, cone-shaped spines; dactylus slender and curved. Urosome: urosomite 1 flat, no carina nor hump, nor keel. Uropod 1: peduncle, 1.12x longer than outer ramus with three lateral spines; outer ramus $1.15 x$ longer than inner ramus with thre dorsomedial spines; inner ramus, with two dorso medial spines. Uropod 2: peduncle, length, 0.94x than outer ramus; outer ramus longer than inner, lengh $1.35 \mathrm{x}$ inner, with four dorsomedial spines, without constriction; inner ramus with two dorsomedial spines, without constriction. Uropod 3: peduncle short, length $0.78 \mathrm{x}$ outer ramus; rami stout without plumose setae; outer ramus 2 -articulate, article 2 very short, length $0.25 x$ article 1 , with two apical spines; inner ramus distinctly shorter than outer, length $0.74 \mathrm{x}$ outer ramus. Telson: $1.3 \mathrm{x}$ longer than broad, half length cleft $(50 \%)$, reaching just past peduncle of uropod 3 .

Complementary description. Due to insufficient character condition of epimeron of the holotype specimen a complementary description of a paratype male (ZMB 30508) is given. 
Epimeron 1: anterior margin slightly concave; anteroventral corner rounded; posteroventral corner convex, broadly rounded. Epimeron 2: anteroventral corner convex, rounded; posteroventral corner bluntly subquadrate. Epimeron 3: anteroventral corner convex, broadly rounded; posterior margin straight; posteroventral corner subacutely rounded, not produced.

Colour pattern. This species has brownish pigmentation forming transverse stripes on each segment of the pereon and pleon (Fig. 3a). This colour pattern might fade or disappear altogether following preservation.

Size. 4.0-5.5 $\mathrm{mm}$ (based on type series).

Sexual dimorphism. In males antenna 2 is longer than antenna 1, while in females antenna 2 is subequal to antenna 1. Moreover, males bear calceoli on antennae 1 and 2, wheras females lack calceoli on antennae 1 and 2. Distribution and depth. King George Island, Potter Cove (30-40 m, present study), Marian Cove (0.5 m, Kim et al. 2014), Admiralty Bay (10 m, Jażdżewski et al. 1991; 5-10 cm, underneath waterline, Jażdżewski et al. 2001).

Biology. The scavenger status of this species remains unclear since the species did only occure in very low numbers in baited traps in this study. Due to the fact that it was attracted to bait bearing mouthparts typical for feeding on animal carcasses it is assumed that $O$. infinita is, at least, a facultative carrion-feeder. Jażdżewski et al. (2001) reported this species as an epibenthic dweller being also able to burrow in sediments.

Remarks. $O$. infinita sp. n. is most closly related to $O$. ultima but differs from this species in having the anterior margin of lateral lobe of the head broader and more convex, article 1 of the flagellum of antenna 1 is much shorter, not elongate (broader than long, not longer than broad as in O. ultima) and article 1 of the accessory flagellum is not strongly elongated (2,5x longer than broad) as it is in O. ultima (5x longer than broad). Urosomite 1 has no dorsal depression, no carina or hump while O. ultima has a deep dorsal depression followed by a prominent rounded dorsal hump.

The newly described species $O$. infinita has been detected in several earlier studies (e.g. Jażdżewski et al. 1991; Jażdżewski et al. 2001; Kim et al. 2014). It was identified as Orchomenella cf. ultima and morphological differences were already discussed by Jażdżewski et al. (1991) and Kim et al. (2014). After a detailed examination of the holotype of O. ultima, the original description of Bellan-Santini (1972), and a careful examination of the specimens within this study, the morphological differences between our specimens and $O$. ultima are evident and justify the description of a new species. Since the holotype specimen of $O$. ultima, stored at Museo Civico di Storia Naturale, Verona, Italy, MSNVRCr479, is in a fragile condition and the history of fixation is unknown, we decided not to risk a destruction of the valuable material for DNA extraction. 


\section{Discussion}

\section{Species inventory and identification}

Taxonomic misidentifications can have serious consequences for subsequent data analyses especially for population assessments and conservation managements (Metcalf et al. 2007; Beerkircher et al. 2009), but also for evolutionary and ecology-based research (Bortolus 2008). It is therefore recommended that an integrative taxonomic approach should be conducted whenever possible. Our results are in large agreement with the general performance of DNA barcoding data in marine metazoans (Bucklin et al. 2011), crustaceans (Costa et al. 2007) including marine amphipods and demonstrated the identification potential of an integrative approach combining morphology and genetics (Radulovici et al. 2009; Havermans et al. 2010, 2011; Havermans 2012).

In our integrated study of scavenging lysianassoid amphipods from Potter Cove we contributed to the biodiversity inventory of the Antarctic marine fauna by analysing more than 43,900 amphipod specimens representing ten lysianassoid species in two families. Momo et al (1998) investigated the amphipod species composition from outer Potter Cove only. In their study they recorded three lysianassid species: Cheirimedon dentimanus Chevreux, 1905, Valettia coheres Stebbing, 1888 and Orchomenella acanthurus (Schellenberg, 1931). C. dentimanus is a junior synonym of $C$.femoratus (Chilton 1913; Lowry 2010). The record of V. coheres is very likely the result of a misidentification. This species belongs to a little known deep-sea genus, comprising only two species. In the study of Casaux et al. (1990) the occurrence of $V$.coheres was reported as a component of the algal bed fauna in Potter Cove, without giving any evidence and reference for this. Besides the questionable records of Casaux et al. (1990) and Momo et al. (1998), only one specimen of V. coheres is known, subsequently designated as the holotype (Thurston and Allen, 1969). The sibling species Valettia hystrix Thurston, 1989 is only known from the alimentary canal of two species of holothurian collected in the North East Atlantic Ocean (Thurston 1989). In addition, the type locality of V.coheres is in the Southern Ocean Indian Ocean sector but at more than $3600 \mathrm{~m}$ depth (Stebbing, 1888). For this reason, it is very unlikely that $V$. coheres is found sub-littorally and not more frequently in an Antarctic sampling hotspot such as the western Antarctic islands. It is herein postulated that the records of V. coheres by Casaux et al. (1990) and Momo et al. (1998) are misidentifications.

\section{Intra- or interspecific morphological variation?}

We investigated if two colour morphs (red and white) of $H$. kergueleni might represent two distinct species. 
Species delimitation has been carried out successfully on the basis of colouration and subsequently supported by molecular data in the amphipod Paramphithoe hystrix complex (Schnabel and Hebert 2003) as well as in the decapod Petrolisthes galathinus complex (Hiller et al. 2006, Hiller and Werding 2007). However, in our study, both colour morphs of $H$. kergueleni can not be distinguished by molecular data. A similar case of a species bearing distinct morphotypes, but with pairwise genetic divergence values within the intraspecific range (max. 4\% K2P distance) both in mitochondrial (CO1, 16S rDNA; 0-1\% mean K2P distance) as well as in nuclear marker (28S rDNA; 0\% mean K2P distance) was described for the Antarctic deep-sea lysianassoid Eurythenes andhakarae D'Udekem d'Acoz and Havermans, 2015 (Havermans et al. 2013; d'Udekem d'Acoz and Havermans, 2015). D'Udekem d'Acoz and Havermans (2015) explained the differences in colour patterns as a result of the interdependence between pigmentation and moult and intermoult stages - a phenomenon already known from the shore crab Carcinus maenas (Linnaeus, 1758) (Baldwin and Smith 1987; Reid et al. 1997; Styrishave et al. 2004; Lewis 2011). This is likely also the case for the two detected morphotypes of $H$. kergueleni.

The species Orchomenella rotundifrons represents another case of a species with a high morphological variability. Due to the fact that some specimens of $O$. rotundifrons share morphological traits fitting to the characteristics of $O$. denticulata without being genetically distinct, we can assume that $O$. denticulata might represents a morphotype within the variability range of $O$. rotundifrons. However, it should be noted that investigations of DNA barcode data or mitochondrial DNA can be misleading or wrong in cases of relatively recent speciation or introgression events (Moritz and Cicero 2004). More detailed analyses with the integration of nuclear data should address the aforementioned taxonomic issues. On the other hand, $\mathrm{CO}$ data can highlight cases of cryptic species complexes, for which amphipods provide well-known examples (e.g. see Costa et al. 2007; Havermans et al. 2011; Havermans 2012; Katouzian et al. 2016). Havermans (2012) revealed two genetically distinct clusters of $W$. obesa (>15\% K2P distance) which we could corroborate with new morphological data, thus supporting their interpretation as reproductively isolated species (nominal W. obesa cluster 'A' and W. obesa cluster 'B'). We included sequences of nominal W. obesa and W. obesa cluster 'B'. sensu Havermans (2012) in our study and have obtained evidence for the occurrence of nominal W. obesa in Potter Cove. 


\section{The influence of sampling method and environmental factors on species occurrences and abundances}

In previous studies in which the amphipod scavenging fauna has been investigated by baited traps, the number of species reported was related to the sampling effort and coverage area. De Broyer et al. (2004) recorded for a sampling effort of 31 baited traps covering the eastern and western Weddell Sea, including King George Island, 37 lysianassoid species from the 70,000 specimens investigated up to $1000 \mathrm{~m}$ depth. A study on deep-sea lysianassoid scavengers from the Mid-Atlantic Ridge (Horton et al. 2013) has given an account of 31 species out of more then 250,000 specimens sampled from sixteen baited trap deployments over a 4-year study period. Results of biodiversity assessments often vary according to the sampling methods and the sample sizes used. In this context, the use of baited traps as a non-quantitative and selective method presents difficulties when estimating species abundances. Scavengers are specifically attracted by chemical cues and the challenges of defining the certain area of attraction has been made a subject of discussion (Gros and Santarelli, 1986; Ingram and Hessler, 1983; Premke et al. 2003; Sainte-Marie and Hargrave, 1987). Sainte-Marie and Hargrave (1987) made an attempt to develop a model for estimating amphipod species abundances inferred from baited traps. They stated that variables such as species-specific swimming speeds, current velocity, site specific eddy diffusivity, bait-specific odour leaking rate and species-specific chemosensory thresholds are critical parameters for estimation models. Without these information the estimation of species abundances inferred from baited traps will not be accurate. Furthermore, bait size, daytime (Sainte-Marie, 1986) and entrance size of the trap also affect the sampling results. However, the use of baited traps for collecting scavenging, mobile organisms such as amphipods helps to avoid sources of errors such as gear avoidance or inefficient retention of (smaller) organisms associated with other commonly used sampling methods (hand nets, Van Veen grabs, epibenthic sledges, trawls). Indeed, these could introduce a sampling bias of unknown magnitude.

The omnivorous scavenger $C$. femoratus is ubiquitously distributed both in the soft sediment dominated part of Potter Cove (inner cove) as well as in the hard substrated area (outer cove). Moreover, C. femoratus occupied a dominant role among scavenging lysianassoids in the inner cove being the only species occurring in high relative abundances and particularly in the recently ice-free areas of Potter Cove. These areas are greatly influenced by the retreat of the Fourcade Glacier as well as by high rates of freshwater run-off and sedimentation caused by the meltwater creeks disemboguing into the cove. This has already led to shifts in the benthic communities and has also created new habitats available for colonization (Quartino et al. 2013; Sahade et al. 2015; Deregibus et al. 2016). Pioneer species as well as species with a broad ecological niche, are expected to occupy new areas within 
the succession process. The sporadic and rare occurrence of other lysianassoid species suggests that the inner cove is not a favourable habitat although potential candidate colonizers are present in the outer cove. Hence, it is very likely that $C$. femoratus is a pioneer species of sublittoral coastal systems, with a broad ecological niche. When compared to the inner cove, the outer cove seems to provide a more suitable habitat for other lysianassoid amphipod species, and this is where the highest numbers of lysianassoid amphipod species were found. This finding indicates that some or all of the conditions present in the inner cove may be challenging to lysianassoid amphipods: shallower depths, the strong influence of sedimentation processes, fluctuating salinity, predominantly soft sediment and low coverage of macroalgae beds (Barrera-Oro and Casaux 1990; Quartino et al. 2013; Sahade et al. 2015). Most of the less abundant species found in our study such as P.plebs, P. rossi, P. coatsi, A. charcoti and W. obesa have been frequently reported at greater depths (De Broyer et al. 2004, 2007; Presler 1986) indicating a preference for deeper waters. However, the conclusion of the aforementioned records could also be biased due to the restricted sampling possibilities for shallow-water samplings on board of a research vessel.

C. femoratus plays an important role in the shallow-water benthic communities of Maxwell Bay, being the only scavenging amphipod species found in high numbers compared to other amphipods (Rauschert 1991; Siciński et al. 2012; Kim et al. 2014). Siciński et al. (2011) reported C. femoratus dominating the necrophagous benthic community of Admiralty Bay in winter while being replaced in summers by H. kergueleni. A smilar seasonal species shift was revealed by Smale et al. (2007) in which a replacement of $C$. femoratus in summers by the nemertean Parborlasia corrugatus (McIntosh, 1876) was reported. Our data did not corroborate this species shift: we found C. femoratus in higher numbers than H. kergueleni in our summer samples. Finally, and in addition to the findings of Kim et al. (2014), who only reported $C$. femoratus and $O$. infinita sp. n., we now can add $H$. kergueleni as well as $O$. rotundifrons to the species list of the sublittoral of Maxwell Bay.

In a compilation of thirty years of benthic biodiversity research from Admiralty Bay, Siciński et al. (2011) listed 27 lysianassoid amphipod species (subsequently corrected into 29 species; pers. communication A. Jażdżewska) sampled by various methods. Eight of the ten lysianassoid species we detected for Potter Cove are also known from Admiralty Bay, while A. charcoti and $O$. pinguides were reported for KGI for the first time. The higher species number for lysianassoid amphipods in Admiralty Bay is not surprising given that a) the amphipod community in Admiralty Bay has been studied for more than 30 years and therefore likely higher due the greater number of total samples investigated, b) the use of additional sampling methods (e.g. netting, van Veen grabs), and c) the larger size of Admiralty Bay (25.3 km coastline) and greater depths (up to $535 \mathrm{~m}$ ), which might favour 
a higher alpha diversity by providing more microhabitats (Siciński et al. 2011). Moreover, variations in soak time, bait quantity and the limited size of trap entrance could have also affected the number of sampled species from Potter Cove. However, assuming that abiotic conditions (e.g. sedimentation, freshwater input) are one of the major limiting factors of the taxonomic diversity of scavenging amphipods in the shallower inner Potter Cove, the increased influence of meltwater-related conditions along the Antarctic Peninsula could lead to similarly impoverished communities in affected habitats. A continuation of studying scavenging amphipods from Potter Cove and understanding the reason for the broad ecological niche of $C$. femoratus will improve future species distribution modelling and predictions on the effects of ongoing and future environmental changes.

\section{Outlook}

As an omnivorous scavenger, the lysianassoid amphipod C. femoratus is a key species Potter Cove food web, illustrated by its wide distribution and high abundances in both the outer and inner cove. It is an important element for the decomposition of organic matter in Potter Cove. A recent study of fish gut content analyses

showed that $C$. femoratus is also an important food source for the locally abundant Antarctic fish species Notothenia rossii Richardson, 1844 at 10 and 20 m depths (Index of relative importance, IRI\%= 19.24; 9.47) as well as for Notothenia coriiceps Richardson, 1844 at 10 and 20 m depths (IRI\%= 4.52; 9.25) (Barrera-Oro et al. unpubl. data). The ecological role of lysianassoid amphipods, but particularly the trophic position of $C$. femoratus in the food web of Potter Cove needs more detailed study as omnivorous species in general do not necessarily have a flexible position in food webs (Johnston et al. 2011). Studies addressing species-specific feeding and decomposition rates (Lastra et al. 2014) as well as stable isotope and fatty acid analyses (Nyssen et al. 2002, 2005) are needed to further elucidate the role and importance of lysianassoid amphipods in the coastal Antarctic ecosystem, which are exposed to a rapidly changing environment due to climate-induced glacier retreat.

Conflict of Interest: The authors declare that they have no conflict of interest.

Ethical approval: All applicable international, national, and/or institutional guidelines for the care and use of animals were followed. 


\section{References}

Allcock AL, Strugnell JM (2012) Southern Ocean diversity: new paradigms from molecular ecology. Trends Ecol Evol 27:520-528. doi: 10.1016/j.tree.2012.05.009

Andres HG (1983) Die Gammaridea (Crustacea: Amphipoda) der Deutschen Antarktis-Expeditionen 1975/76 und 1977/78. 3.Lysianassidae. Mitt Hamb Zool Mus Inst 80:183-220

Arntz W, Gutt J (eds) (1997). The Expedition ANTARKTIS XIII/3 (EASIZ I) of “Polarstern”” to the Eastern Weddell Sea in 1996. Ber Polarforsch 249: 1-148

Arntz WE, Gutt J, Klages M (1997) Antarctic marine biodiversity: an overview. In: Battaglia B, Valencia J, Walton DWH (eds). Antarctic communities: species, structure and survival. Cambridge University Press, Cambridge: $3-14$

Astrin JJ, Stüben PE (2008) Phylogeny in cryptic weevils: molecules, morphology and new genera of western Palaearctic Cryptorhynchinae (Coleoptera: Curculionidae). Invertebr Syst 22: 503-522. doi: 10.1071/IS07057

Baldwin RJ, Smith KL Jr (1987) Temporal variation in the catch rate, length, color and sex of the necrophagous amphipod, Eurythenes gryllus, from the central and eastern North Pacific. Deep-Sea Res 34(3):425-439. doi: $10.1016 / 0198-0149(87) 90146-4$

Barnard JL (1967) Bathyal and abyssal Gammaridean Amphipoda of Cedros Trench, Baja California. U.S. Natl Mus Bull 260:1-205

Barnard KH (1932) Amphipoda. Discov Rep 5:1-326

Barrera-Oro ER, Casaux RJ (1990) Feeding selectivity in Notothenia neglecta Nybelin, from Potter Cove, South Shetland Islands, Antarctica. Antarct Sci 2:207-213. doi: 10.1017/S0954102090000281

Barrera-Oro ER, Piacentino GLM (2007) Feeding habits of juvenile Trematomus newnesi (Pisces, Nototheniidae) at Potter Cove, South Shetland Islands, Antarctica. Polar Biol 30:789-796. doi: 10.1007/s00300006-0238-y

Bellan-Santini D (1972) Amphipodes provenant des contenus stomacaux de trois espèces de poissons Nototheniidae récoltés en Terre Adélie (Antarctique). Tethys 4(3):683-702

Beerkircher L, Arocha F, Barse A, Prince E, Restrepo V, Serafy J, Shivji M (2009) Effects of species misidentification on population assessment of overfished white marlin Tetrapturus albidus and roundscale spearfish T. georgii. Endanger Species Res 9:81-90. doi: 10.3354/esr00234

Birstein YA, Vinogradov ME (1962) Pelagic Gammaridea (Amphipoda) collected by the Soviet Antarctic 
Expedition on the M/V "OB" south of $40^{\circ} \mathrm{S}$. Biological Reports of the Soviet Antarctic Expedition (1955-1958)

Vol. 1. Academy of Sciences of the USSR. Zoological Institute, Moscow, pp 33-56; figs.1-12

Boeck A (1861) Bemærkninger angaaende de ved de norske kyster forekommende amphipoder. Forh Skand Naturf Ott Mod [8th meeting in Copenhagen]: 631-677

Boeck A (1871) Crustacea amphipoda borealia et arctica. Forh Vid Selsk Krist:83-280. doi: 10.5962/bhl.title.2056

Bonnier J (1893) Les amphipodes du Boulonnais (1) Bull Sci Fr Bel 24 (1892):161-207. doi: 10.5962/bhl.part.7782

Bortolus A (2008) Error cascades in the biological sciences: the unwanted consequences of using bad taxonomy in ecology. AMBIO 37(2):114-118. doi: 10.1579/0044-7447(2008)37[114:ECITBS]2.0.CO;2

Brandt A (1999) On the origin and evolution of Antarctic Peracarida (Crustacea, Malacostraca). Sci Mar 63(1):261-274. doi: 10.3989/scimar.1999.63s 1261

Bucklin A, Steinke D, Blanco-Bercial L (2011) DNA barcoding of marine metazoa. Annu Rev Mar Sci 3:471508. doi: 10.1146/annurev-marine-120308-080950

Casaux RJ, Mazzotta AS, Barrera-Oro ER (1990) Seasonal aspects of the biology and diet of nearshore nototheniid fish at Potter Cove, South Shetland Islandas, Antarctica. Polar Biol 11:63-72. doi: 10.1007/BF00236523

Chapelle G, Peck LS (1995) The influence of acclimation and substratum on the metabolism of the Antarctic amphipods Waldeckia obesa (Chevreux, 1905) and Bovallia gigantea (Pfeffer 1888). Polar Biol 15:225. doi: 10.1007/BF00239063

Chevreux E (1905) Diagnoses d'amphipodes nouveaux provenant de l'expédition antarctique du Français. Bull Soc Zool Fr 30:159-165. doi: 10.5962/bhl.part.20370

Chevreux E (1906) Crustacés amphipodes. In: Joubin L (ed) Expédition Antarctique Francaise (1903-1905) commandée par le Dr Jean Charcot. Sciences naturelles: documents scientifiques. Crustacés. Masson et Cie, Paris, pp 1-100

Chevreux E (1912) Deuxième expédition dans l'Antarctique, dirigée par le Dr. Charcot, 1908-1910. Diagnoses d'amphipodes nouveaux. Bull Mus Natl Hist Nat 18(4):208-218

Chilton C (1912) The Amphipoda of the Scottish National Antarctic Expedition. Proc. R. Soc. Edinb. 48(3): $455-520$

Chilton C (1913) Revision of the Amphipoda from South Georgia in the Hamburg Museum. Mitt Nat hist Mus Hamburg 30: 53-63 
Clarke A, Crame JA (1989) The origin of the Southern Ocean marine fauna. In: Crame JA (ed) Origins and evolution of the Antarctic biota. Geol Soc Spec Publ 47, pp 253-268. doi: 10.1144/GSL.SP.1989.047.01.19

Clarke A, Johnston NM (2003) Antarctic marine benthic diversity. In: Gibson RN, Atkinson RJA (eds) Oceanography and Marine Biology: an Annual Review 41. Taylor \& Francis, London \& New York, pp 47-114 Coleman CO (2003) "Digital inking”: How to make perfect line drawings on computers. Org Divers Evol Electr. Suppl 14:1-14. doi: 10.1078/1439-6092-00081

Coleman CO (2009) Drawing setae the digital way. Zoosyst Evol 85(2):305-310. doi: 10.1002/zoos.200900008 Costa FO, de Waard JR, Boutillier J, Ratnasingham S, Dooh RT, Hajibabaei M, Hebert PD (2007) Biological identifications through DNA barcodes: the case of the Crustacea. Can J Fish Aquat Sci 64(2):272-295. doi: 10.1139/f07-008

Corrigan LJ, Horton T, Fotherby H, White TA, Hoelzel AR (2014) Adaptive evolution of deep-sea amphipods from the superfamily Lysiassanoidea in the North Atlantic Evol Biol 41(1):154-165. doi:10.1007/s11692-0139255-2.

Dana JD (1849) Synopsis of the genera of Gammaracea. Am J Sci Arts 2(8):135-140

Dauby P, Scailteur Y, De Broyer C (2001) Trophic diversity within the eastern Weddell Sea amphipod community. Hydrobiologia 443:69-86. doi: 10.1023/A:1017596120422

De Broyer C (1973) Notes sur les Orchomene (Amphipodes, Lysianassidae) de l'Océan Austral. I.Description d'Orchomene hureaui n.sp. de Terre Adélie. Bull Inst R Sci Nat Belg: Biol 49(7):1-12

De Broyer C (1984) Evolution du Complexe Orchomene Boeck (Amphipoda, Lysianassidae). Ann Soc R Zool Belg 114(1):197-198

De Broyer C (1985) Amphipodes lysianassoïdes nécrophages des îles Kerguelen (Crustacea: 1. Orchomenella guillei n. sp. Bull Mus Natl Hist Nat (ser 4) 7(1):205-217

De Broyer C, Nyssen F, Dauby P (2004) The crustacean scavenger guild in Antarctic shelf bathyal and abyssal communities. Deep-Sea Res Part II Top Stud Oceanogr 51:1733-1752. doi: 10.1016/j.dsr2.2004.06.032

De Broyer C, Lowry JK, Jażdżewski K, Robert H (2007) Catalogue of the Gammaridean and Corophiidean Amphipoda (Crustacea) of the Southern Ocean with distribution and ecological data. In: De Broyer C (ed) Census of Antarctic Marine Life: Synopsis of the Amphipoda of the Southern Ocean. Bull Inst R Sci Nat Belg: Biol. 77(1):1-325

De Broyer C, Danis B et al (2011) How many species in the Southern Ocean? Towards a dynamic inventory of the Antarctic marine species. Deep-Sea Res Part II Top Stud Oceanogr 58:5-17. doi: 10.1016/j.dsr2.2010.10.007 De Broyer C, Jażdżewska A (2014) Biogeographic patterns of Southern Ocean benthic amphipods In: De Broyer 
C, Koubbi P, Griffiths HJ, Raymond B, d'Udekem d'Acoz C et al (eds). Biogeographic Atlas of the Southern Ocean. Scientific Committee on Antarctic Research, Cambridge, pp 155-165

Deregibus D, Quartino ML, Campana GL, Momo FR, Wiencke C, Zacher K (2016) Photosynthetic light requirements and vertical distribution of macroalgae in newly ice-free areas in Potter Cove, South Shetland Islands, Antarctica. Polar Biol 39:153-166. doi: 10.1007/s00300-015-1679-y

D'Udekem d'Acoz C (2010) Contribution to the knowledge of European Liljeborgiidae (Crustacea, Amphipoda), with considerations on the family and its affinities. Bull Inst r sci nat Belg, Entomol Biol 80:127259

D`Udekem d`Acoz C, Havermans C (2012) Two new Pseudorchomene species from the Southern Ocean, with phylogenetic remarks on the genus and related species (Crustacea: Amphipoda: Lysianassoidea: Lysianassidae: Tryphosinae). Zootaxa 3310:1-50

D'Udekem d`Acoz C, Havermans C (2015) Contribution to the systematics of the genus Eurythenes S.I. Smith in Scudder, 1882 (Crustacea: Amphipoda: Lysianassoidea: Eurytheneidae). Zootaxa 3971:001-080

Falk U, Gieseke H, Kotzur F, Braun M (2015) Monitoring snow and ice surfaces on King George Island, Antarctic Peninsula, with high-resolution TerraSAR-X time series. Antarct Sci 1(2):1-15. doi: $10.1017 / \mathrm{S} 0954102015000577$

Fuentes V, Alurralde G, Meyer B, Aguirre G, Canepa A, Wölfl AC, Hass HC, Williams GN, Schloss IR (2016) Glacial melting: an overlooked threat to Antarctic krill. Sci Rep 6:27234. doi: 10.1038/srep27234

Gros P, Santarelli L (1986) Méthode d'estimation de la surface de pêche d'un casier à l'aide d'une filière expérimentale. Oceanol Acta 9:81-87

Gurjanova E (1938) Amphipoda, Gammaroidea zalikov Siaukhu i Sudzukhe (Yaponskoe More). [Amphipoda, Gammaroidea of Siaukhu Bay and Sudzukhe Bay (Japan Sea)] Reports of the Japan Sea Hydrobiological Expedition of the Zoological Institute of the Academy of Sciences USSR in 1934 1:241-404

Gurjanova E (1962) Bokoplavy severnoi chasti Tikhogo okeana (Amphipoda, Gammaridea). Chast 1. [Amphipods of the northern part of Pacific Ocean (Amphipoda, Gammaridea). Part 1.] Opredeliteli po faune SSSR, Akademiia Nauk SSSR 74:1-—440

Gutt J (2016) Research on climate-change impact on Southern Ocean and Antarctic ecosystems after the UN Paris climate conference-_"now more than ever" or "set sail to new shores"?. Polar Biol. doi: $10.1007 / \mathrm{s} 00300-016-2059-\mathrm{y}$

Havermans C (2012) DNA barcoding, phylogeography and phylogeny of the Lysianassoidea (Crustacea: Amphipoda) from the Southern Ocean and the world's deep seas. Dissertation, Université Catholique de Louvain 
Havermans C, Nagy ZT, Sonet G, De Broyer C, Martin P (2010) Incongruence between molecular phylogeny and morphological classification in amphipod crustaceans: a case study of Antarctic lysianassoids. Mol Phylogenet Evol 55:202-209. doi: 10.1016/j.ympev.2009.10.025

Havermans C, Nagy ZT, Sonet G, De Broyer C, Martin P (2011) DNA barcoding reveals new insights into diversity of Antarctic species of Orchomene sensu lato (Crustacea: Amphipoda: Lysianassoidea). Deep-Sea Res Part II Top Stud Oceanogr 58:230-241. doi: 10.1016/j.dsr2.2010.09.028

Havermans C, Sonet G, D`Udekem d’Acoz C, Nagy ZT, Martin P, Brix S, Riehl T, Agrawal S, Held C (2013) Genetic and morphological divergences in the cosmopolitan depp-sea amphipod Eurythenes gryllus reveal a diverse abyss and a bipolar species. PLoS ONE 8(9): e74218. doi: 10.1371/journal.pone.0074218

Heller C (1868) Crustaceen. In: Reise der Österreichischen Fregatte Novara um die Erde in den Jahren 1857 , 1858, 1859 unter den Befehlen des Commodore B. von Wüllerstorf-Urbair, Zoologischer Theil 2 (3). Wien, Kaiserlich-Königliche Staatsdruckerei 1861-75:128-129. doi: 10.5962/bhl.title.1597

Hiller A, Kraus H, Almon M, Werding B (2006) The Petrolisthes galathinus complex: Species boundaries based on color pattern, morphology and molecules, and evolutionary interrelationships between this complex and other

Porcellanidae (Crustacea: Decapoda: Anomura). Mol Phylogenet Evol 40:547-569. 10.1016/j.ympev.2006.03.030

Hiller A, Werding B (2007) Redescription of Petrolisthes edwardsii (de Saussure) and description of a new, sibling species from the eastern Pacific based on different colour, morphology and genetic identity (Crustacea: Anomura: Porcellanidae). Org Divers Evol 7:181-194. doi: 10.1016/j.ode.2006.06.002

Horton T, MH Thurston, Duffy GA Community composition of scavenging amphipods art bathyal depths on the Mid-Atlantic Ridge. Deep-Sea Res Part II Top Stud Oceanogr 98: 352-359. doi: 10.1016/j.dsr2.2013.01.032 Horton T, Lowry J, Costello M, Bellan-Santini D (2016) Orchomenella Sars, 1890. In: Horton T; Lowry J, De Broyer C, Bellan-Santini D; Coleman CO, Daneliya M, Dauvin J-C, Fišer C, Gasca R, Grabowski M,. GuerraGarcía JM, Hendrycks E, Holsinger J, Hughes L, Jaume D, Jażdżewski K, Just J, Kamaltynov RM, Kim Y-H, King R, Krapp-Schickel T, LeCroy S, Lörz A-N, Senna AR, Serejo C, Sket B, Tandberg AH, Thomas J, Thurston M, Vader W, Väinölä R, Vonk R, White K, Zeidler W (2016) World Amphipoda Database. http://www.marinespecies.org/amphipoda./aphia.php?p=taxdetails\&id=101634. Accessed 17 November 2016 Hurley DE (1963) Amphipoda of the family Lysianassidae from the west coast of North and Central America. Allan Hancock Found Publ Occas Pap 25:1-160

Hurley DE (1965) A common but hitherto undescribed species of Orchomenella (Crustacea: Amphipoda:family Lysianassidae) from the Ross Sea. Trans Roy Soc N.Z. 6 (11):107-113 
Ingólfsson A, Agnarsson I (1999) Anonyx sarsi: a major unrecognized scavenger and predator in the intertidal zone. J. Mar. Biol. Assoc. U. K. 79(6):1127-8.

Ingram CL, Hessler RR (1983) Distribution and behavior of scavenging amphipods from the central North Pacific. Deep- Sea Res Part I Oceanogr Res Pap 30(7):683-706. doi: 10.1016/0198-0149(83)90017-1

Jażdżewska A (2011) Soft bottom sublittoral amphipod fauna of Admiralty Bay, King George Island, Antarctic. Oceanol Hydrobiol Stud 40(1):1-10. doi: 10.2478/s13545-011-0001-z

Jażdżewski K (1981) Amphipod crustaceans in the diet of pygoscelid penguins of the King George Island, South Shetland Island, Antarctica. Pol Polar Res 2:133-144

Jażdżewski K, De Broyer C, Pudlarz M, Zielinski D (2001) Seasonal fluctuation of vagile benthos in the uppermost sublittoral of a maritime Antarctic fjord. Polar Biol 24:910-917. doi: 10.1007/978-3-642-59419-9_13 Jażdżewski K, De Broyer C, Teodorczyk W, Konopacka A (1992) Survey and distributional patterns of the amphipod fauna of Admiralty Bay, King George Island, South Shetland Islands. Pol Polar Res12(3):461-472

Jażdżewski K, Teodorczyk W, Siciński J, Kontek B (1991) Amphipod crustaceans as an important component of zoobenthos of the shallow Antarctic sublittoral. Hydrobiologia 223:105-117. doi: 10.1007/978-94-011-3542$9 \_10$

Jażdżewski K, Weslawski JM, De Broyer C (1995) A comparison of the amphipod faunal diversity in two polar fjords: Admiralty Bay, King George Island (Antarctic) and Hornsund, Spitsbergen (Arctic). Pol Arch Hydrobiol 42(4):367-384

Jażdżewski K, Konopacka A (1999) Necrophagous lysianassoid Amphipoda in the diet of Antarctic tern at King George Island, Antarctica. Antarct Sci 11(3):316-321. doi: 10.1017/S0954102099000401

Johnston K, Robson BJ, Fairweather PG (2011) Trophic positions of omnivores are not always flexible: Evidence from four species of freshwater crayfish. Austral Ecol 36:269-279. doi: 10.1111/j.14429993.2010.02147.x

Katoh K, Misawa K, Kuma KI, Miyata T (2002) MAFFT: a novel method for rapid multiple sequence alignment based on fast Fourier transform. Nucleic Acids Res 30(14):3059-3066. doi: 10.1093/nar/gkf436

Katouzian AR, Sari A, Macher JN, Weiss M, Saboori A, Leese F, Weigand AM (2016) Drastic underestimation of amphipod biodiversity in the endangered Irano-Anatolian and Caucasus biodiversity hotspots. Sci Rep 6:22507. doi: $10.1038 /$ srep22507

Kearse M, Moir R, Wilson A, Stones-Havas S, Cheung M, Sturroc S, Thierer T (2012) Geneious Basic: an integrated and extendable desktop software platform for the organization and analysis of sequence data. Bioinformatics 28(12):1647-1649. doi: 10.1093/bioinformatics/bts199 
Kim J-H, Jażdżewska A, Choi H-G, Kim W (2014) The first report on Amphipoda from Marian Cove, King George Island, Antarctic. Oceanol Hydrobiol Stud 43(1):106-113. doi: 10.2478/s13545-014-0122-2

Klöser H, Ferreyra G, Schloss I, Mercuri G., Laturnus F, Curtosi A (1994) Hydrography of Potter Cove, a small fjord-like inlet on King George Island (South Shetlands). Estuar Coast Shelf Sci 38:523-537. doi: 10.1006/ecss. 1994.1036

Krapp- Schickel T (2011) New Antarctic stenothoids sensu lato (Amphipoda, Crustacea). Eur J Taxon 2:1-17. doi: $10.5852 /$ ejt.2011.2

Krøyer HN (1846) Crustacés. In: P. Gaimard, Voyages de la commission scientifique du nord, en Scandinavie, en Laponie, au Spitzberg et aux Feroe, pendant les années 1838- 1840, sur la corvette «La Recherche», commandée par M. Fabvre. Atlas pp 10-11, 13-20, 22-23

Lastra M, Rodil IF, Sánchez-Mata A, García-Gallego, Mora J (2014) Fate and processing of macroalgal wrack subsidies in beaches of Deception Island, Antarctic Peninsula. J Sea Res 88: 1-10. doi: 10.1016/j.seares.2013.12.011

Latreille PA (1816) Amphipodes. In: Biot J-B, Bosc L-A-G, Chaptal J-A, Desmarest A-G, Dutour M, Huzard JB, Lamarck J-B-P-A, de Monet de, Latreille PA, Lucas J-A-H, Olivier G-A, Palisot de Beauvois A- M-F-J, Parmentier A-G, Patrin E-M-L, Richard L-C, Sonini C-S, Thouin A, Tollard C, Vieillot L-P, Virey J- J, Yvart JA-V. Nouveau dictionnaire d'histoire naturelle, appliquée aux arts, à l'agriculture, à l'économie rurale et domestique, à la médecine, etc. 2nd edition. Vol. 1. Librairie Deterville, Imprimerie d'Abel Lanoe, Paris, lxxix pp 467-469

Legeżyńska J, Węsławski J and Presler P (2000) Benthic scavengers collected by baited traps in the high Arctic Polar Biol 23(8): 539-544. doi:10.1007/s003000000118

Lewis J (2011) Red and green Carcinus: how different? The Plymouth Student Scientist 4(1):423-431

Linnaeus C (1758) Systema Naturae per regna tria naturae, secundum classes, ordines, genera, species, cum characteribus, differentiis, synonymis, locis. Editio decima, reformata. Laurentius Salvius: Holmiae. ii, 824 pp

Lönnberg AJE (1906) Contributions to the fauna of South Georgia. I. Taxonomic and biological notes on vertebrates. K Sven Vetensk Akad Handl 40(5):1-104

Lowry JK (2010) Cheirimedon dentimanus Chevreux, 1905. In: Horton T, Lowry J, De Broyer C, Bellan-Santini D, Coleman CO, Daneliya M, Dauvin J-C, Fišer C, Gasca R, Grabowski M, Guerra-García JM, Hendrycks E, Holsinger J, Hughes L, Jazdzewski K, Just J, Kamaltynov RM, Kim Y-H, King R, Krapp-Schickel T, LeCroy S, Lörz A-N, Senna A-R, Serejo C, Sket B, Tandberg AH, Thomas J, Thurston M, Vader W, Väinölä R, Vonk R, White K, Zeidler W (2015) World Amphipoda Database. 
http:/www.marinespecies.org/amphipoda/aphia.php?p=taxdetails\&id=526264. Accessed 04 December 2016.

Lowry JK, Kilgallen NM (2014) A revision of the lysianassid genus Waldeckia with the description of four new species (Crustacea, Amphipoda, Lysianassidae, Waldeckiinae subfam. nov.). Zootaxa 3784(4):301-345

Lowry JK, Stoddart HE (1983) The shallow-water gammaridean Amphipoda of the sub-Antarctic islands of New Zealand and Australia: Lysianassoidea. J R Soc N. Z. 13(4):279-394. doi: 10.1080/03036758.1983.10420804 Lowry JK, Stoddart HE (1997) Amphipoda Crustacea IV. Families Aristiidae, Cyphocarididae, Endevouridae, Lysianassidae, Scopelocheiridae, Uristidae. Mem Hourglass Cruises 10(1):1-148

McIntosh WC (1876) XXXI.--Descriptions of some new species of Annelida from Kerguelen's Island, Ann Natur Hist 17(100): 318-323. doi: 10.1080/00222937608681956

Metcalf JL, Pritchard VL, Silvestri SM, Jenkins JB, Wood JS, Cowley DE, Evans R, Shiozawa DK, Martin AP (2007) Across the great divide: genetic forensics reveals misidentification of endangered cutthroat trout populations. Mol Ecol 16(21):4445-4454. doi: 10.1111/j.1365-294X.2007.03472.x

Miers EJ (1875) Descriptions of new species of Crustacea collected at Kerguelen's Island by the Rev. A. E. Eaton. Ann Mag Nat Hist (ser. 4) 16:73-76

Momo F, Bogazzi E, Duttweiler F (1998) Amphipods of Potter Cove: Community composition, biology and growth In: Wiencke C, Ferreyra G, Arntz W, Rinaldi C (eds). The Potter Cove coastal ecosystem, Antarctica synopsis of research performed within the frame of the Argentinean -German cooperation at the Dallmann Laboratory and Jubany Station (King George Island, Antarctica, 1991 -1997). Ber Polarforsch 299

Moreira E (2015) Antarctic Ichthyofauna: Ecology of juvenile fish of the Suborder Notothenioidei from Potter Cove, King George Island/ Isla 25 de Mayo. Dissertation, Universidad Nacional de La Plata

Moreira E, Seefeldt M, Valli Francione M, Schloss I, Quartino L, Barrera-Oro E (2016) Feeding selectivity in Notothenia coriiceps and $N$. rossii (Pisces, Nototheniidae) on benthos, mainly amphipods, at Potter Cove, South Shetland Islands, Antarctica. XXXIV SCAR Open Science Conference. August 2016, Kuala Lumpur, Malaysia Moritz C, Cicero C (2004) DNA barcoding: promise and pitfalls. PLoS Biology 2(10):e354. doi: 10.1371/journal.pbio.0020354

Nagata K (1965) Studies on marine gammaridean amphipoda of the Seto Inland Sea. I. Publ Seto Mar Biol Lab 13(2):131-170

Nyssen F, Brey T, Lepoint G, Bouquegneau J-M, De Broyer C, Dauby P (2002) A stable isotope approach to the eastern Weddell Sea trophic web: focus on benthic amphipods. Pol Biol 25(4):280-287. doi: 10.1007/s00300001-0340-0

Nyssen F, Brey T, Dauby P, Graeve M (2005) Trophic position of Antarctic amphipods - enhanced analysis by a 
2-dimensional biomarker assay. Mar Ecol Prog Ser 300:135-145. doi:10.3354/meps300135

Pasotti F, Manini E, Giovannelli D, Wölfl AC, Monien D, Verleyen E, Braeckman U, Abele D, Vanreusel A (2014) Antarctic shallow water benthos under glacier retreat forcing. Mar Ecol 36(3):716-733. doi: 10.1111/maec. 12179

Pfeffer G (1888) Die Krebse von Süd-Georgien nach der Ausbeute der Deutschen Station 1882-83. 2.Teil. Die Amphipoden. Lütcke und Wulff, Hamburg. doi: 10.5962/bhl.title.10084

Poulin E, Palmab AT, Féralc JP (2002) Evolutionary versus ecological success in Antarctic benthic invertebrates. Trends Ecol Evol 17(5):218-222. doi: 10.1016/S0169-5347(02)02493-X

Premke K, Muyakshin S, Klages M, Wegner J (2003) Evidence for long-range chemoreceptive tracking of food odour in deep-sea scavengers by scanning sonar data. J Exp Mar Biol Ecol 285-286:283-294. doi: 10.1016/S0022-0981(02)00533-6

Presler P (1986) Necrophagous invertebrates of the Admiralty Bay of King George Island (South Shetland Islands, Antarctica). Pol Polar Res 7:25-61

Quartino ML, Deregibus D, Campana GL, Latorre GEJ, Momo FR (2013) Evidence of Macroalgal Colonization on Newly Ice-Free Areas following Glacial Retreat in Potter Cove (South Shetland Islands), Antarctica. PLoS ONE 8(3):e58223. doi:10.1371/journal.pone.0058223

Radulovici AE, Sainte-Marie B, Dufresne F (2009) DNA barcoding of marine crustaceans from the Estuary and Gulf of St Lawrence: a regional-scale approach. Mol Ecol Resour 9(s1):181-187. doi: 10.1111/j.17550998.2009.02643.x

Ratnasingham S, Hebert PD (2007) BOLD: The Barcode of Life Data System (http://www. barcodinglife. org). Mol Ecol Notes 7(3):355-364. doi: 10.1111/j.1471-8286.2007.01678.x

Rauschert M (1988) Gammaridea (Crustacea, Amphipoda) Aus der Küstenregion von King George (SüdShetland-Inseln). Podoceridae. Mitt Zool Mus Berl 64(2):299-310. doi: 10.1002/mmnz.19880640206

Rauschert M (1989) Atylopsis fragilis n. sp. (Crustacea, Amphipoda, Gammaridea, Eusiridae) aus dem Sublitoral von King George (Süd-Shetland-Inseln). Mitt Zool Mus Berl 65(1):127-138. doi: 10.1002/mmnz.19890650104 Rauschert M (1990) New amphipods from the sublittoral of King george Island faunistic contribution to ecological investigations. Geodatische und Geophysikalische Veröffentlichungen 16:447-458

Rauschert M (1991) Ergebnisse der faunistischen Arbeiten im Benthal von King George Island (Süd-ShetlandInseln, Antarktis). Ber Polarforsch 76:1-75

Rauschert M (1995) Zwei neue Vertreter der Gammaridea (Crustacea, Amphipoda) aus dem Sublitoral bei Livingston Island (Südshetlandinseln). Mitt Zool Mus Berl 71(1):11-26. doi: 10.1002/mmnz.19950710104 
Reid DG, Abelló P, Kaiser MJ, Warman CG (1997) Carapace colour, inter-moult duration and the behavioural and physiological ecology of the shore crab Carcinus maenas. Estuar Coast Shelf Sci 44(2):203-211. doi: $10.1006 /$ ecss. 1996.0212

Richardson J (1844) Ichthyology. Part 1. In: Hinds RB (ed) The Zoology of the Voyage of H. M. S. Sulphur, under the Command of Captain Sir Edward Belcher, R. N.,C. B., F. R. G. S., etc., during the years 1836-42, No. 5.Smith, Elder \& Co, London, Ichthy Voyage Sulphur 1:51-70. doi: 10.5962/bhl.title.7364

Rückamp M, Braun M, Suckro S, Blindow N (2011) Observed glacial changes on the King George Island ice cap, Antarctica, in the last decade. Glob Planet Change 79:99-109. doi: 10.1016/j.gloplacha.2011.06.009

Sahade R, Lagger C, Torre L, Momo F, Monien P, Schloss I, Barnes DKA, Servetto N, Tarantelli S, Tatián M, Zamboni N, Abele D (2015) Climate change and glacier retreat drive shifts in an Antarctic benthic ecosystem. Sci Adv 1(10): e1500050. doi: 10.1126/sciadv.1500050

Sainte-Marie B (1986) Effect of bait size and sampling time on the attraction of the lysianassid amphipods Anonyx sarsi Steele \& Brunel and Orchomenella pinguis (Boeck). J Exp Mar Biol Ecol 99(1):63-77. doi: $10.1016 / 0022-0981(86) 90021-3$

Sainte-Marie B, Hargrave BT (1987) Estimation of scavenger abundance and distance of attraction to bait. Mar Biol 94(3):431-443

Sars GO (1890) An account of the Crustacea of Norway with short descriptions and figures of all the species. Vol. 1 Amphipoda. Christiana and Copenhagen, Cammermeyers ALB, Oslo, pp 1-68

Sars GO (1891) Amphipoda. Part IV. Lysianassidae (Continued). An account of the Crustacea of Norway, with short descriptions and figures of all the species. Christiana and Copenhagen, Cammermeyers ALB, Oslo, I:6992

Schellenberg A (1931) Gammariden und Caprelliden des Magellangebietes, Südgeorgiens und der Westantarktis. Further Zoological Results of the Swedish Antarctic Expedition 1901-1903 2(6):1-290

Schloss IR, Wasilowska A, Dumont D, Almandoz GO, Hernando MP, Michaud-Tremblay C-A, Saravia L, Rzepecki M, Monien P, Monien D, Kopczyńska EE, Bers AV, Ferreyra GA (2014) On the phytoplankton bloom in coastal waters of southern King George Island (Antarctica) in January 2010: An exceptional feature?. Limnol Oceanogr 59(1):195-210. doi: 10.4319/1o.2014.59.1.0195

Schnabel KE, Hebert PDN (2003) Resource-associated divergence in the Arctic marine amphipod Paramphithoe hystrix. Mar Biol 143:851-857. doi:10.1007/s00227-003-1126-4

Siciński J, Jażdżewski K, De Broyer C, Presler P, Ligowski R, Nonato EF, Corbisier TN, Petti MAV, Brito TAS, Lavrado HP, Błażewicz-Paskowycz M, Pabis K, Jażdżewska A, Campos LS (2011) Admiralty Bay Benthos 
Diversity - A census of a complex polar ecosystem. Deep-Sea Res Part II Top Stud Oceanogr 58(1-2):30-48. doi: $10.1016 /$ j.dsr2.2010.09.005

Siciński J, Pabis K, Jażdżewski K, Konopacka A, Błażewicz-Paskowycz M (2012) Macrozoobenthos of two Antarctic glacial coves: a comparison with non-disturbed bottom areas. Polar Biol 35:355-367. doi:10.1007/s00300-011-1081-3

Slattery PN, Oliver JS (1986) Scavenging and other feeding habits of Lysianassid amphipods (Orchomene spp.) from McMurdo Sound, Antarctica. Polar Biol 6:171-177. doi:10.1007/BF00274880

Smale DA, Barnes DKA, Fraser KPP, Mann PJ, Brown MP (2007) Scavenging in Antarctica: Intense variation between sites and seasons in shallow benthic necrophagy. J Exp Mar Biol Ecol 349(2):405-417

Stebbing TRR (1888) Report on the Amphipoda collected by H.M.S. Challenger during the years 1873-1876. Report on the Scientific Results of the Voyage of H.M.S. Challenger during the years 1873-76. Zoology 29:11737

Styrishave B, Rewitz K, Andersen O (2004) Frequency of moulting by shore crabs Carcinus maenas (L.) changes their colour and their success in mating and physiological performance. J Exp Mar Biol Ecol 313(2):317-336. doi: 10.1016/j.jembe.2004.08.013

Tamura K, Stecher G, Peterson D, Filipski A, Kumar S (2013) MEGA6: molecular evolutionary genetics analysis version 6.0. Mol Biol Evol 30(12):2725-2729. doi 10.1093/molbev/mst197

Thurston MH and Allen EA (1969) Type material of the families Lysianassidae, Stegocephalidae, Ampeliscidae and Haustoriidae (Crustacea: Amphipoda) in the collections of the British Museum (Natural History). Bull br Mus nat Hist Zool 17: 347-388

Thurston MH (1989) A new species of Valettia (Crustacea: Amphipoda) and the relationship of the Valettidae to the Lysianassoidea. J Nat Hist 23:093-1107. doi: 10.1080/00222938900770991

Turner J, Barrand NE, Bracegirdle TJ, Convey P, Hodgson DA, Jarvis M, Jenkins A, Marshall GJ, Meredith MP, Roscoe HK, Shanklin JD, French J, Goosse H, Guglielmin M, Gutt J, Jacobs SS, Kennicutt MCI, MassonDelmotte V, Mayewski P, Navarro F, Robinson S, Scambos T, Sparrow M, Speer K, Summerhayes CP, Klepikov AV (2014) Antarctic Climate Change and the Environment - An Update. Polar Rec: 50 (254):237-259 doi:10.1017/S0032247413000296

Turner J, Colwell SR, Marshall GJ, Lachlan-Cope TA, Carleton AM, Jones PD, Lagun V, Reid, PA, Lagovkina S (2005) Antarctic climate change during the last 50 years. Int J Climatol 25(3):279-294. doi:10.1002/joc.1130 Walker AO (1903) Amphipoda of the "Southern Cross" Antarctic Expedition. Zool J Linn Soc 29:38-64 Walker AO (1906) Preliminary descriptions of new species of Amphipoda from the 'Discovery' Antarctic 
Expedition, 1902-1904. Ann Mag Nat Hist (Ser. 7) 17:452-458

Walker AO (1907) Crustacea. III. Amphipoda. National Antarctic Expedition 1901-1904. Natural History 3, 138

Wickins JF 1983 Catches of large lysianassid amphipods in baited traps at the Nuclear Energy Authority dump site during June 1979. Deep-Sea Res Part I Oceanogr Res Pap. doi: 10.1016/0198-0149(83)90035-3

Wiencke C, Ferreyra G, Abele D, Marenssi S (eds) (2008) The Antarctic ecosystem Potter Cove, King George Island (Isla 25 de Mayo) Synopsis of research performed 1999-2006 at the Dallmann Laboratory and Jubany. Station. Ber Polar Meeresf 571

Wiencke C, Ferreyra G, Arntz W, Rinaldi C (eds) (1998) The Potter Cove coastal ecosystem, Antarctica synopsis of research performed within the frame of the Argentinean -German cooperation at the Dallmann Laboratory and Jubany Station (King George Island, Antarctica, 1991 -1997). Ber Polarforsch 299

Wölfl A-C, Lim CH, Hass HC, Lindhorst S, Tosonotto G, Lettmann KA, Kuhn G, Wolff J-O, Abele D (2014) Distribution and characteristics of marine habitats in a subpolar bay based on hydroacoustics and bed shear stress estimates-Potter Cove, King George Island, Antarctica. Geo-Mar Lett 34:435-446. doi:10.1007/s00367-0140375-1 


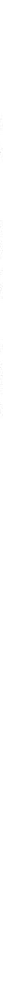

Fig. 1 Sampling stations in Potter Cove and Marian Cove.

MB: Maxwell Bay; AB: Admiralty Bay.

Map data: DIGITALGLOBE 2014, WorldView-2 scene

103001001F612100, Image Courtesy of / Copyright (C) DigitalGlobe

- Longmont, Colorado. All rights reserved.

Catalog ID: 103001001F612100, Acq Date: 2013/03/07,

Sensor: WV02, Band Info: Pan_MS1_MS2, Resolution 0.5*0.5m;

ESRI, DigitalGlobe, GeoEye, Earthstar Geographics, CNES/Airbus DS, USDA, USGS, AEX, Getmapping, Aerogrid, IGN, IGP, swisstopo, and the GIS User Community 

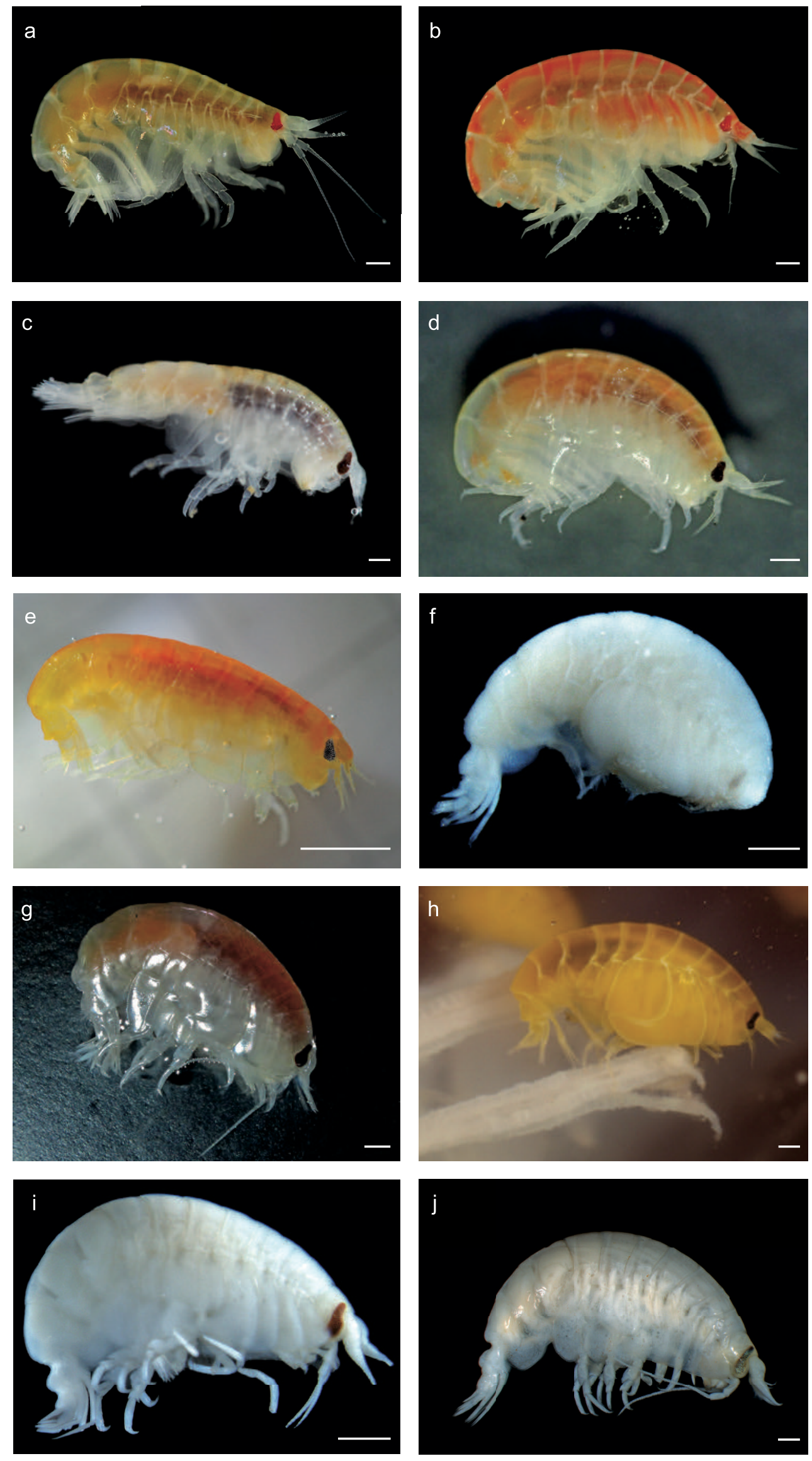

Fig. 2 Lysianassoid amphipod species of Potter Cove. Scale bars correspond to $1 \mathrm{~mm} . \mathrm{f}, \mathrm{i}, \mathrm{j}$ ) post mortem
a) Hippomedon kergueleni white colour morph
b) Hippomedon kergueleni red colour morph
c) Abyssorchomene charcoti
d) Cheirimedon femoratus
e) Orchomenella rotundifrons
f) Orchomenella pinguides
g) Pseudorchomene rossi
h) Waldeckia obesa
i) Pseudorchomene coatsi
j) Pseudorchomene plebs 
a
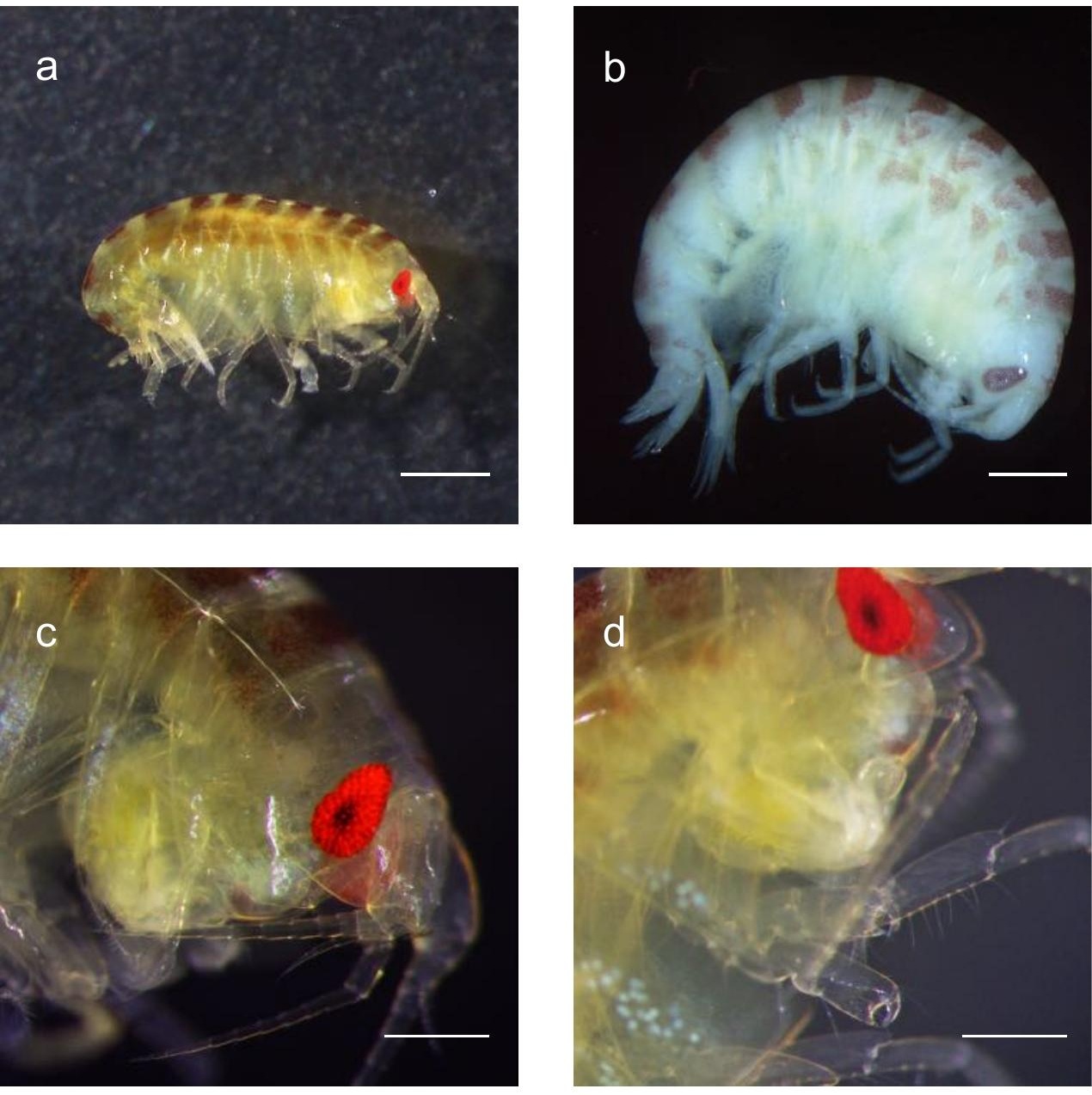

Fig. 3 Orchomenella infinita sp. n., holotype, female, $5.5 \mathrm{~mm}$; Potter Cove, station 9. a, c, d) in vivo b) preserved in ethanol. a +b) habitus and colour pattern, scale bars correspond to $1 \mathrm{~mm} . \mathrm{c}+\mathrm{d}$ ) scale bars correspond to $250 \mu \mathrm{m} \mathrm{c}$ ) emphasizing antenna $1 \mathrm{~d}$ ) emphasizing epistome and upper lip and chelation of gnathopod 2 


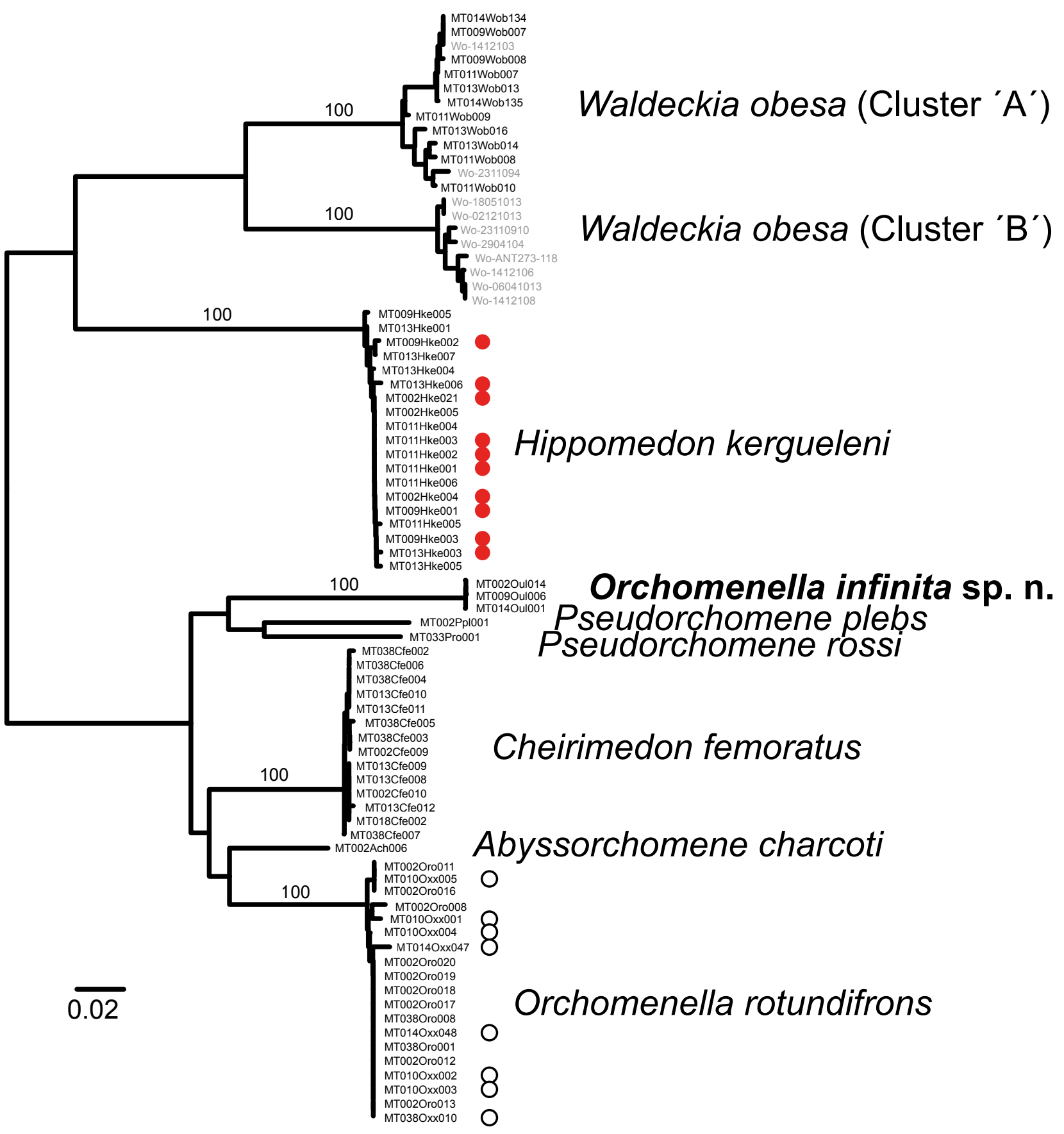

Fig. 4 Mid point rooted neighbour-joining tree of COI sequences of lysianassoid species based on $\mathrm{K} 2 \mathrm{P}$ distances. Bootstrap values with full support are shown (number of replicates=1000). Red dot: red colour morph in Hippomedon kergueleni. White dot: morphological variability present in Orchomenella rotundifrons. Sequences shown in light grey represent data from Havermans (2012). Specimen information can be found in Table 2 


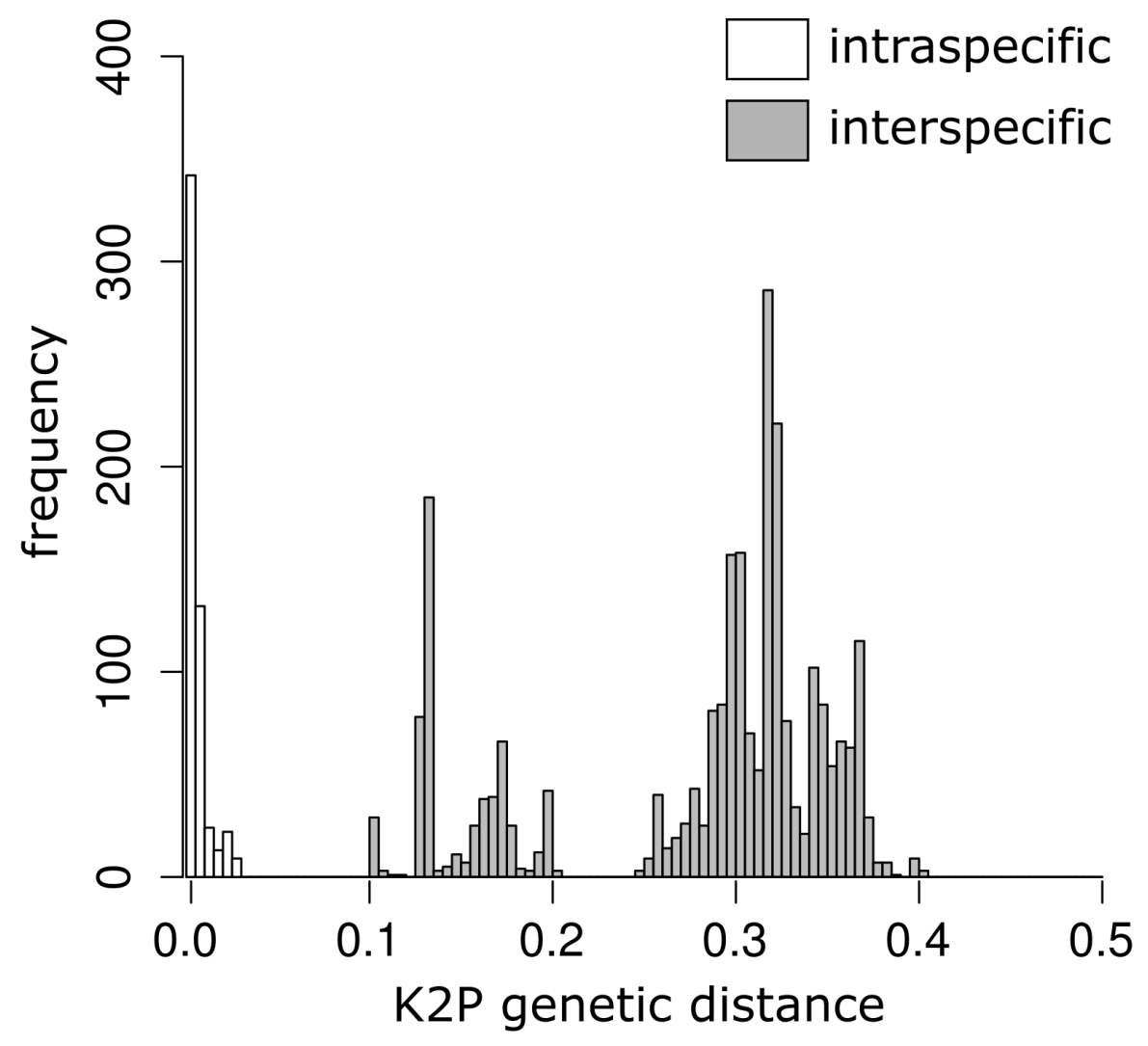

Fig. 5 Frequency distribution of pairwise K2P distances within and between Antarctic lysianassoid species 


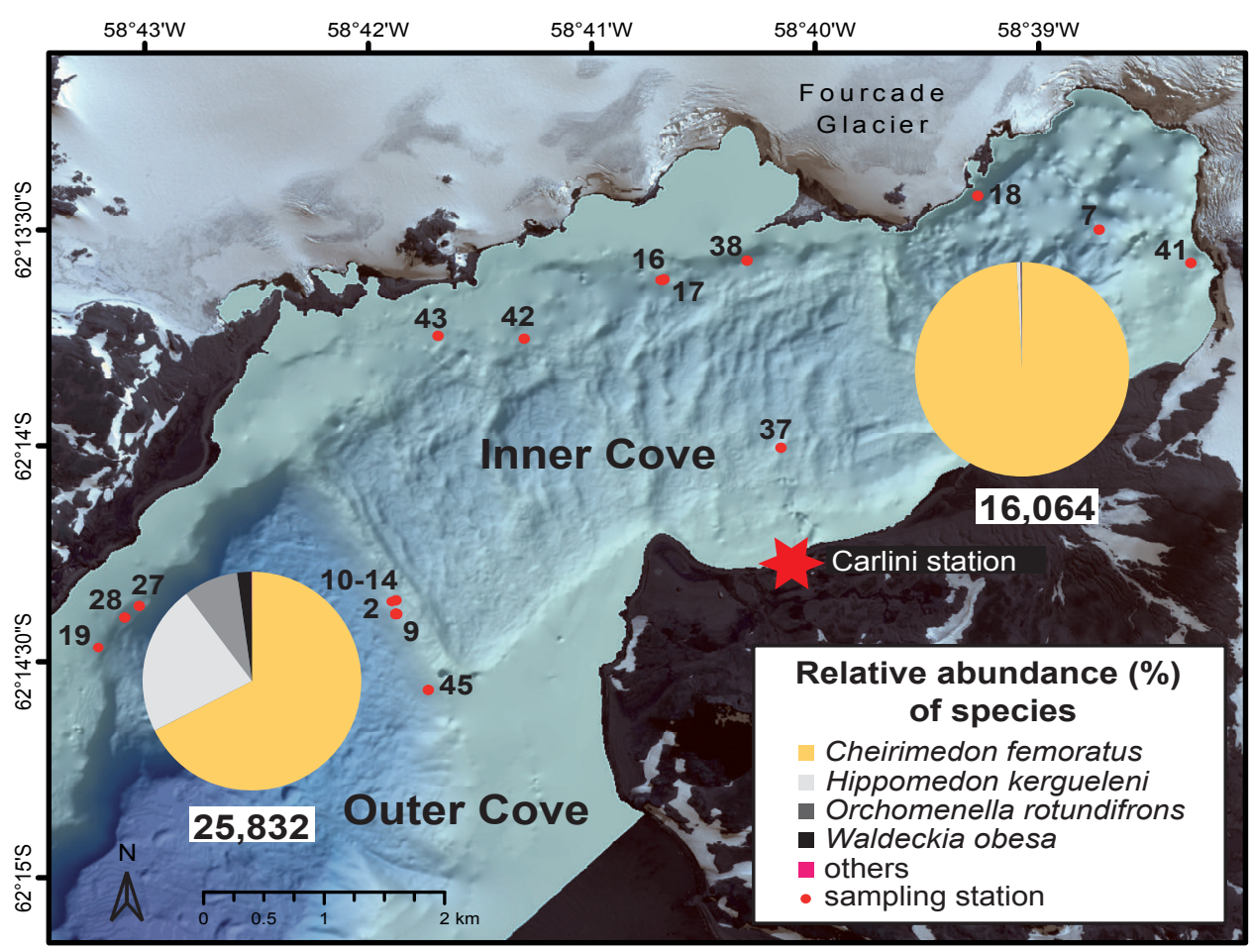

Fig. 6 Relative abundances (\%) of lysianassoid amphipod species found in Potter Cove (outer cove, inner cove). Numbers below pie charts depict the total number of specimens found at respective locations. Further information can be found in Table 4 and supplementary material 1. Map data: DIGITALGLOBE 2014, WorldView-2 scene 103001001F612100, Image Courtesy of / Copyright (C DigitalGlobe - Longmont, Colorado. All rights reserved.

Catalog ID: 103001001F612100, Acq Date: 2013/03/07, Sensor: WV02, Band Info: Pan_MS1_MS2, Resolution $0.5 * 0.5 \mathrm{~m}$ 


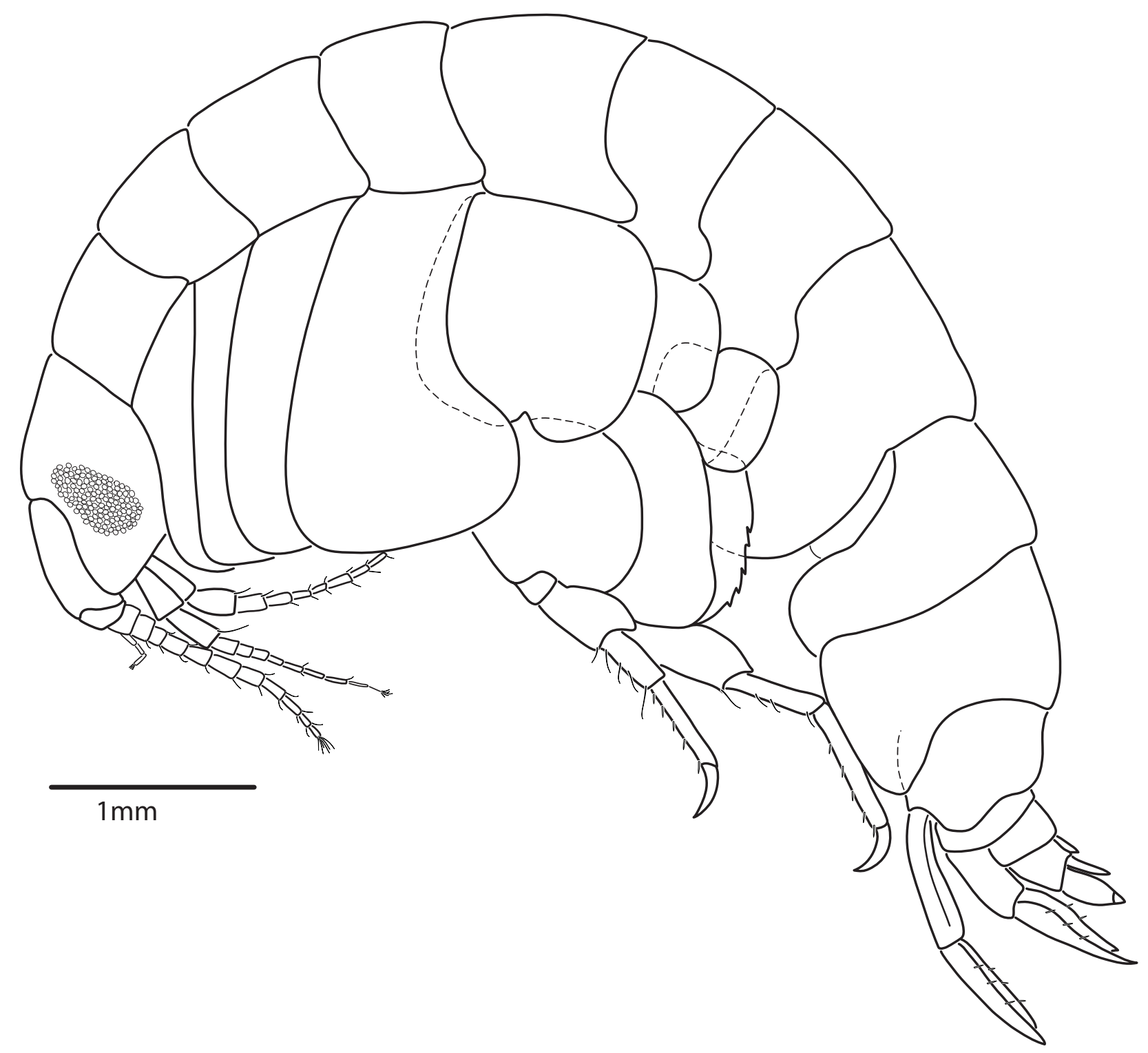

Fig. 7 Habitus of Orchomenella infinita sp. n., holotype, female, $5.5 \mathrm{~mm}$; Potter Cove, station 9 


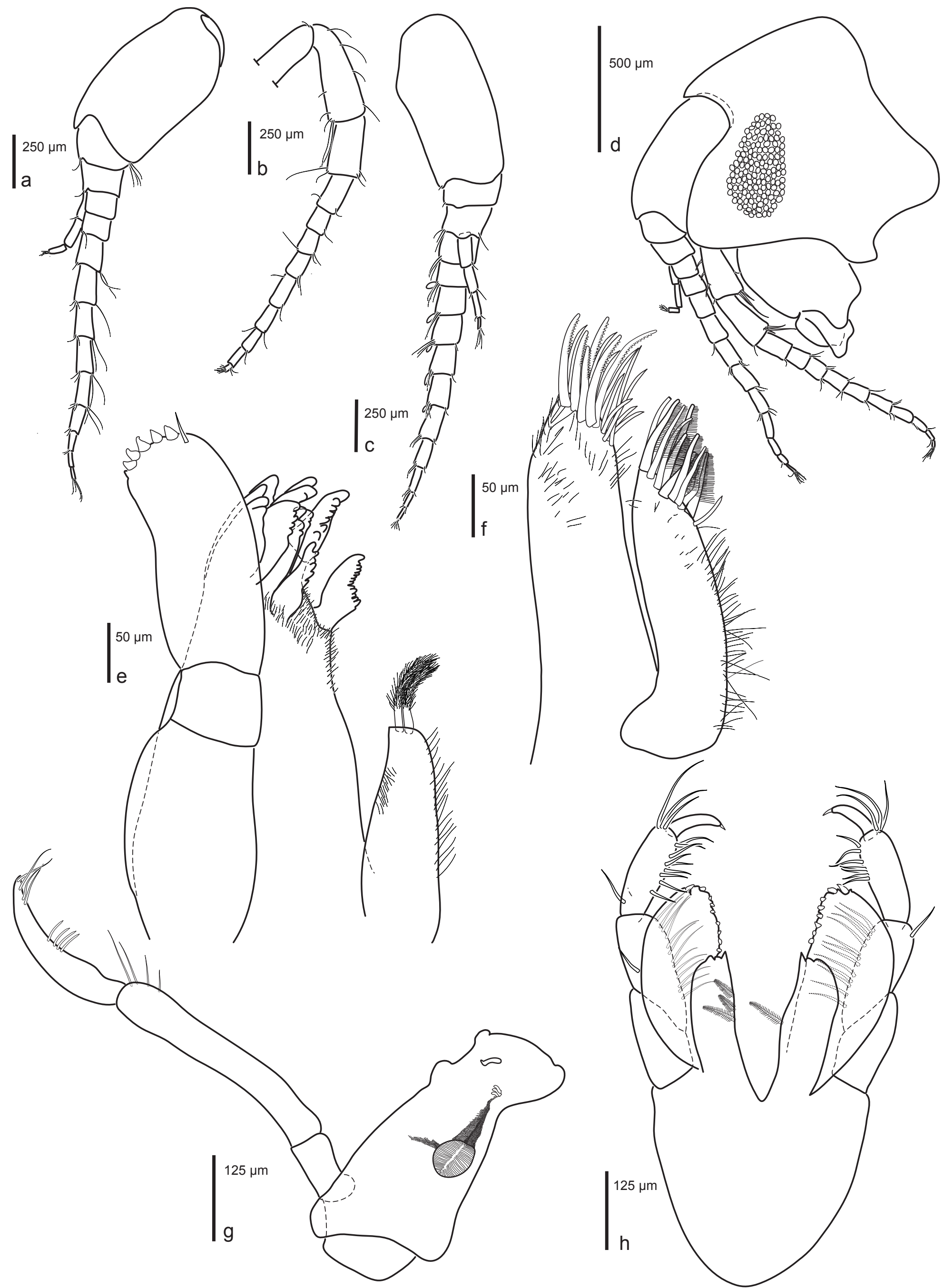

Fig. 8 Orchomenella infinita sp. n., holotype, female, $5.5 \mathrm{~mm}$; Potter Cove, station 9. a) left A1 b) left A2 d) head, antennae, epistome and upper lip e) left Mx1 f) left Mx2 g) left MD h) Mxp. Orchomenella infinita sp. n., paratype, male, $4 \mathrm{~mm}$; Potter Cove station 14. c) left A1 


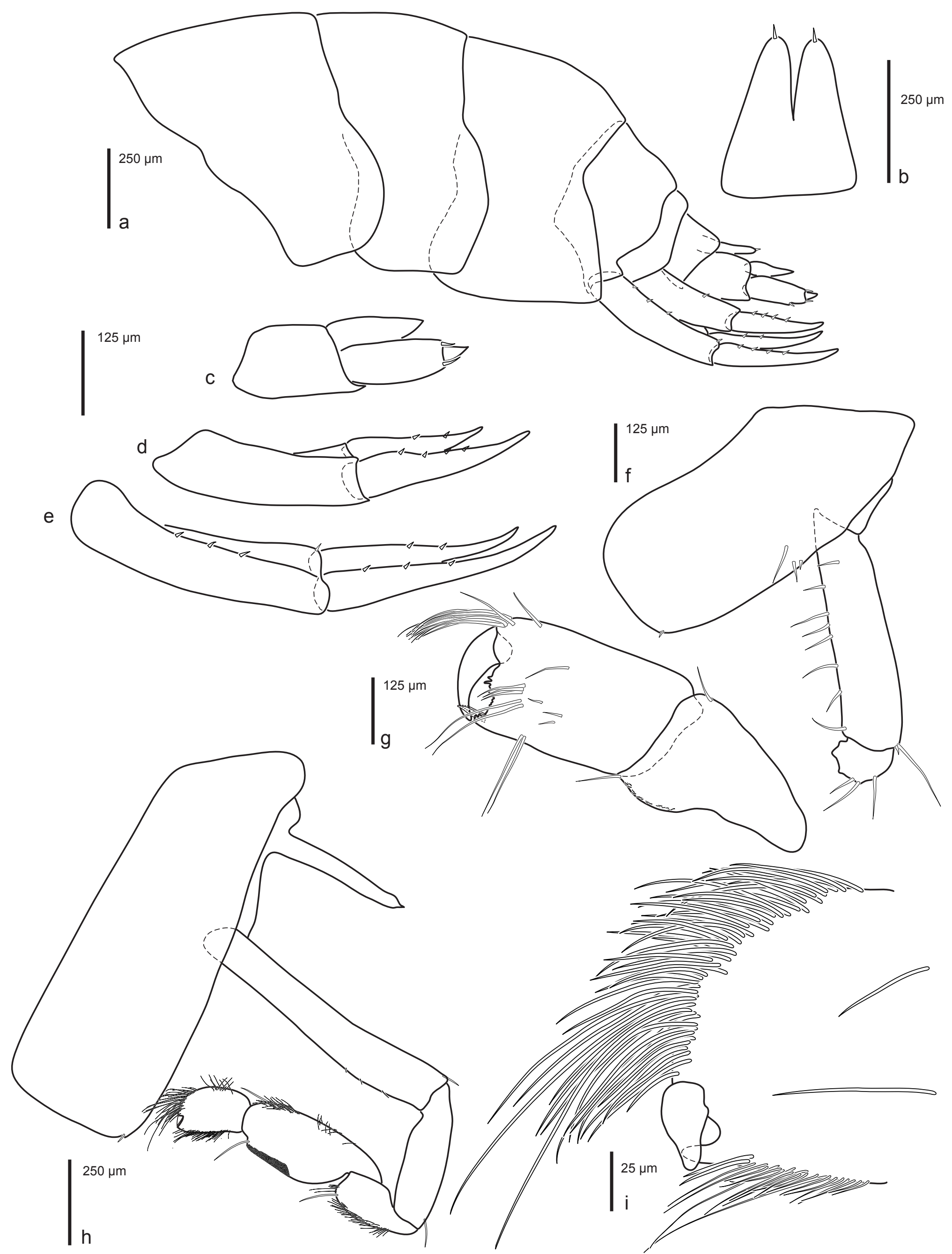

Fig. 9 Orchomenella infinita sp. n., holotype, female, $5.5 \mathrm{~mm}$; Potter Cove, station 9. b) telson c) left U3 d) left U2 e) left $\mathrm{U} 3 \mathrm{f}$ ) left $\mathrm{Gn} 1: \mathrm{Cx}, \mathrm{Ba}$, Is g) left Gn1 Ca, Pr h) left Gn2 i) left Gn2 distal part of Ca. Orchomenella infinita sp. n., paratype, male, $4 \mathrm{~mm}$; Potter Cove station 14. a) Ep 1-3, Uros1-3, U1-3 


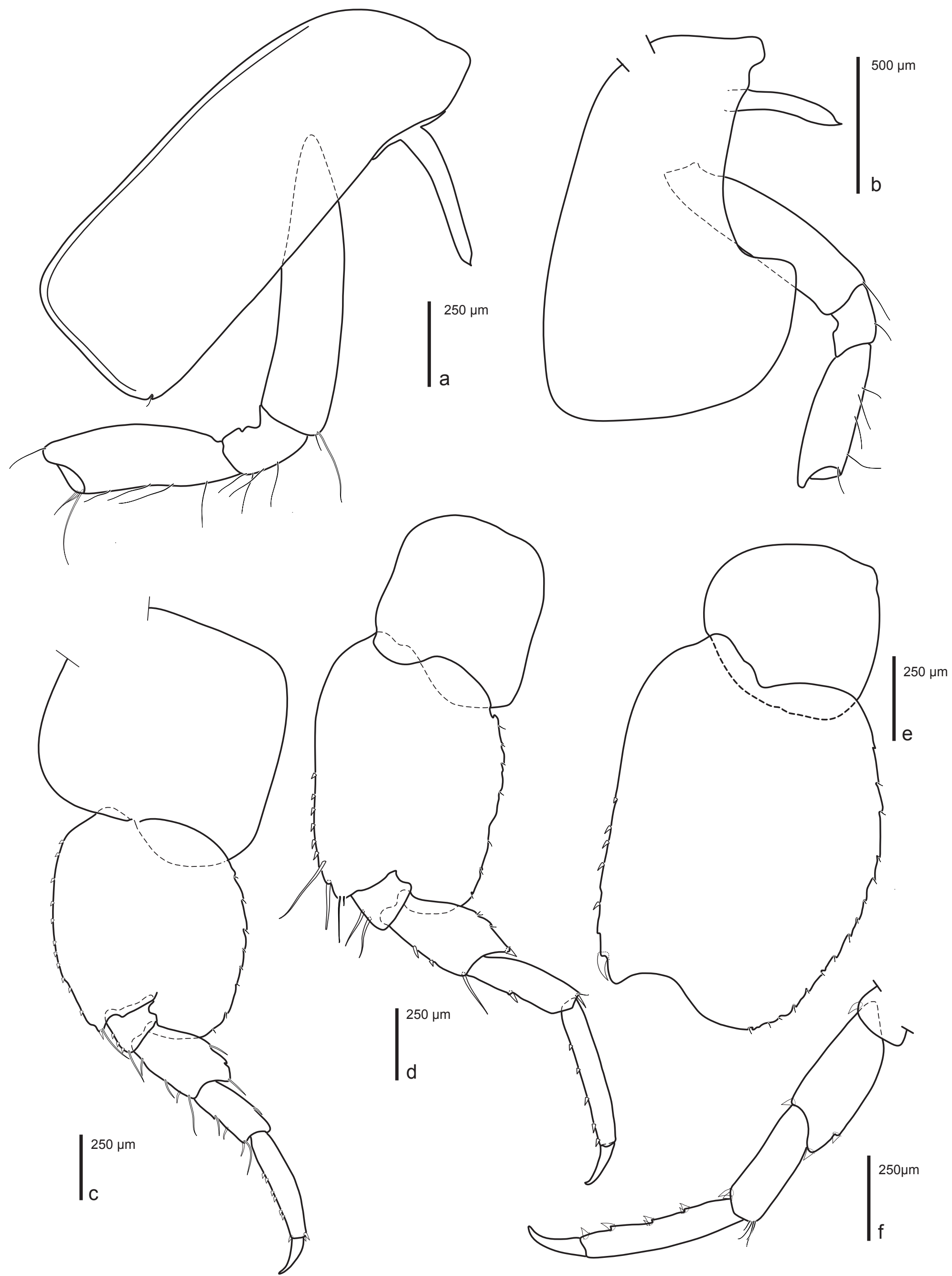

Fig. 10 Orchomenella infinita sp. n., holotype, female, 5.5 mm; Potter Cove, station 9. a) left P3: Cx, Ba, Is, Me b) left P4: $\mathrm{Cx}, \mathrm{Ba}, \mathrm{Is}, \mathrm{Me}$ c) left P5 d) left P6 e) left P7:Cx, Ba f) left P7: Me, Ca, Pr, D 
Table 1 Sampling stations in Potter Cove and Marian Cove analysed in the present study

\begin{tabular}{|c|c|c|c|c|}
\hline Station ID & Locality & Coordinates & Depth & Date \\
\hline 02 & King George Island, Potter Cove, outer cove & $62^{\circ} 14^{\prime} 03.2^{\prime \prime} \mathrm{S} 58^{\circ} 39^{\prime} 17.3^{\prime \prime} \mathrm{W}$ & $30 \mathrm{~m}$ & 14.11 .2014 \\
\hline 07 & King George Island, Potter Cove, inner cove & $62^{\circ} 13^{\prime} 30.1^{\prime \prime S} 58^{\circ} 38^{\prime} 43.7^{\prime \prime} \mathrm{W}$ & $43 \mathrm{~m}$ & 13.12 .2014 \\
\hline 09 & King George Island, Potter Cove, outer cove & $62^{\circ} 14^{\prime} 23.4^{\prime \prime} \mathrm{S} 58^{\circ} 41^{\prime} 52.3^{\prime \prime} \mathrm{W}$ & $39 \mathrm{~m}$ & 16.12 .2014 \\
\hline 10 & King George Island, Potter Cove, outer cove & $62^{\circ} 14^{\prime} 23.4^{\prime \prime} \mathrm{S} 58^{\circ} 41^{\prime} 52.5^{\prime \prime} \mathrm{W}$ & $40 \mathrm{~m}$ & 16.12 .2014 \\
\hline 11 & King George Island, Potter Cove, outer cove & $62^{\circ} 14^{\prime} 23.4^{\prime \prime} \mathrm{S} 58^{\circ} 41^{\prime} 52.5^{\prime \prime} \mathrm{W}$ & $40 \mathrm{~m}$ & 18.12 .2014 \\
\hline 12 & King George Island, Potter Cove, outer cove & $62^{\circ} 14^{\prime} 23.4^{\prime \prime} \mathrm{S} 58^{\circ} 41^{\prime} 52.5^{\prime \prime} \mathrm{W}$ & $40 \mathrm{~m}$ & 18.12 .2014 \\
\hline 13 & King George Island, Potter Cove, outer cove & $62^{\circ} 14^{\prime} 23.4^{\prime \prime} \mathrm{S} 58^{\circ} 41^{\prime} 52.5^{\prime \prime} \mathrm{W}$ & $40 \mathrm{~m}$ & 20.12 .2014 \\
\hline 14 & King George Island, Potter Cove, outer cove & $62^{\circ} 14^{\prime} 23.4^{\prime \prime} \mathrm{S} 58^{\circ} 41^{\prime} 52.5^{\prime \prime} \mathrm{W}$ & $40 \mathrm{~m}$ & 20.12 .2014 \\
\hline 16 & King George Island, Potter Cove, inner cove & $62^{\circ} 13^{\prime} 36.9^{\prime \prime} \mathrm{S} 58^{\circ} 40^{\prime} 40.5^{\prime \prime} \mathrm{W}$ & $28 \mathrm{~m}$ & 22.12 .2014 \\
\hline 17 & King George Island, Potter Cove, inner cove & $62^{\circ} 13^{\prime} 37.0^{\prime \prime} \mathrm{S} 58^{\circ} 40^{\prime} 40.9^{\prime \prime} \mathrm{W}$ & $20 \mathrm{~m}$ & 24.12 .2014 \\
\hline 18 & King George Island, Potter Cove, inner cove & $62^{\circ} 13^{\prime} 25.3^{\prime \prime S} 58^{\circ} 39^{\prime} 16.3^{\prime \prime} \mathrm{W}$ & $19 \mathrm{~m}$ & 24.12 .2014 \\
\hline 19 & King George Island, Potter Cove, outer cove & $62^{\circ} 14^{\prime} 23.6^{\prime \prime} \mathrm{S} 58^{\circ} 43^{\prime} 07.2^{\prime \prime} \mathrm{W}$ & $21 \mathrm{~m}$ & 26.12 .2014 \\
\hline 27 & King George Island, Potter Cove, outer cove & $62^{\circ} 14^{\prime} 22.3^{\prime \prime S} 58^{\circ} 43^{\prime} 01.4^{\prime \prime} \mathrm{W}$ & $30 \mathrm{~m}$ & 03.01 .2015 \\
\hline 28 & King George Island, Potter Cove, outer cove & $62^{\circ} 14^{\prime} 23.9^{\prime \prime} \mathrm{S} 58^{\circ} 43^{\prime} 05.3^{\prime \prime} \mathrm{W}$ & $20 \mathrm{~m}$ & 03.01 .2015 \\
\hline 31 & King George Island, Marian Cove & $62^{\circ} 12^{\prime} 47.8^{\prime \prime} \mathrm{S} 58^{\circ} 47^{\prime} 37.1^{\prime \prime} \mathrm{W}$ & $30 \mathrm{~m}$ & 08.01 .2015 \\
\hline 32 & King George Island, Marian Cove & $62^{\circ} 12^{\prime} 46.5^{\prime \prime} \mathrm{S} 58^{\circ} 47^{\prime} 26.3^{\prime \prime} \mathrm{W}$ & $40 \mathrm{~m}$ & 08.01 .2015 \\
\hline 33 & King George Island, Marian Cove & $62^{\circ} 12^{\prime} 49.4^{\prime \prime S} 58^{\circ} 44^{\prime} 55.2^{\prime \prime} \mathrm{W}$ & $25 \mathrm{~m}$ & 08.01 .2015 \\
\hline 35 & King George Island, Marian Cove & $62^{\circ} 12^{\prime} 25.1^{\prime \prime S ~} 58^{\circ} 46^{\prime} 19.9^{\prime \prime} \mathrm{W}$ & $20 \mathrm{~m}$ & 10.01 .2015 \\
\hline 37 & King George Island, Potter Cove, inner cove & $62^{\circ} 14^{\prime} 00.3^{\prime \prime} \mathrm{S} 58^{\circ} 40^{\prime} 09.1^{\prime \prime} \mathrm{W}$ & $30 \mathrm{~m}$ & 10.01 .2015 \\
\hline 38 & King George Island, Potter Cove, inner cove & $62^{\circ} 13^{\prime} 34.3^{\prime \prime} \mathrm{S} 58^{\circ} 40^{\prime} 18.2^{\prime \prime} \mathrm{W}$ & $20 \mathrm{~m}$ & 10.01 .2015 \\
\hline 41 & King George Island, Potter Cove, inner cove & $62^{\circ} 13^{\prime} 34.6^{\prime \prime} \mathrm{S} 58^{\circ} 38^{\prime} 19.1^{\prime \prime} \mathrm{W}$ & $12 \mathrm{~m}$ & 24.02 .2016 \\
\hline 42 & King George Island, Potter Cove, inner cove & $62^{\circ} 13^{\prime} 45.1^{\prime \prime} \mathrm{S} 58^{\circ} 41^{\prime} 18.0^{\prime \prime} \mathrm{W}$ & $20 \mathrm{~m}$ & 01.03 .2016 \\
\hline 43 & King George Island, Potter Cove, inner cove & $62^{\circ} 13^{\prime} 44.7^{\prime \prime} \mathrm{S} 58^{\circ} 41^{\prime} 41.2^{\prime \prime} \mathrm{W}$ & $13 \mathrm{~m}$ & 01.03 .2016 \\
\hline 45 & King George Island, Potter Cove, outer cove & $62^{\circ} 14^{\prime} 33.9^{\prime \prime} \mathrm{S} 58^{\circ} 41^{\prime} 43.8^{\prime \prime} \mathrm{W}$ & $35 \mathrm{~m}$ & 24.02 .2016 \\
\hline
\end{tabular}


Table 2 Information of $\mathrm{CO} 1$ barcoded specimens including information of W. obesa (Cluster 'A' and 'B') generated by Havermans (2012)

\begin{tabular}{|c|c|c|c|c|c|c|c|}
\hline Morphospecies & ID Code & BOLD ID & $\begin{array}{l}\text { Museums ID } \\
\text { ZMB }\end{array}$ & Locality & $\begin{array}{l}\text { Expedition/ } \\
\text { station ID }\end{array}$ & Coordinates & Depth \\
\hline Orchomenella cf. rotundifrons & MT014Oxx047 & LYAPO001-16 & 30509 & Potter Cove, outer cove & $\begin{array}{l}\text { Carlini 14-15 } \\
\text { st } 14\end{array}$ & $62^{\circ} 14^{\prime} 23.4^{\prime \prime} \mathrm{S}, 58^{\circ} 41^{\prime} 52.5^{\prime \prime} \mathrm{W}$ & $40 \mathrm{~m}$ \\
\hline Orchomenella cf. rotundifrons & MT010Oxx003 & LYAPO002-16 & 30510 & Potter Cove, outer cove & $\begin{array}{l}\text { Carlini 14-15 } \\
\text { st } 10\end{array}$ & $62^{\circ} 14^{\prime} 23.4^{\prime \prime S}, 58^{\circ} 41^{\prime} 52.5^{\prime \prime} \mathrm{W}$ & $40 \mathrm{~m}$ \\
\hline Orchomenella rotundifrons & MT038Oro008 & LYAPO003-16 & 30511 & Potter Cove, inner cove & $\begin{array}{l}\text { Carlini 14-15 } \\
\text { st } 38\end{array}$ & $62^{\circ} 13^{\prime} 34.3^{\prime \prime} \mathrm{S} 58^{\circ} 40^{\prime} 18.2^{\prime \prime} \mathrm{W}$ & $20 \mathrm{~m}$ \\
\hline Orchomenella rotundifrons & MT038Oro001 & LYAPO004-16 & 30512 & Potter Cove, inner cove & $\begin{array}{l}\text { Carlini 14-15 } \\
\text { st } 38\end{array}$ & $62^{\circ} 13^{\prime} 34.3^{\prime \prime} \mathrm{S} 58^{\circ} 40^{\prime} 18.2^{\prime \prime} \mathrm{W}$ & $30 \mathrm{~m}$ \\
\hline Orchomenella rotundifrons & MT002Oro019 & LYAPO005-16 & 30513 & Potter Cove, outer cove & $\begin{array}{l}\text { Carlini 14-15 } \\
\text { st } 02\end{array}$ & $62^{\circ} 14^{\prime} 03.2^{\prime \prime} \mathrm{S}, 58^{\circ} 39^{\prime} 17.3^{\prime \prime} \mathrm{W}$ & $20 \mathrm{~m}$ \\
\hline Orchomenella rotundifrons & MT002Oro017 & LYAPO006-16 & 30514 & Potter Cove, outer cove & $\begin{array}{l}\text { Carlini 14-15 } \\
\text { st } 02\end{array}$ & $62^{\circ} 14^{\prime} 03.2^{\prime \prime S}, 58^{\circ} 39^{\prime} 17.3^{\prime \prime} \mathrm{W}$ & $30 \mathrm{~m}$ \\
\hline Orchomenella cf. rotundifrons & MT038Oxx010 & LYAPO007-16 & 30515 & Potter Cove, inner cove & $\begin{array}{l}\text { Carlini 14-15 } \\
\text { st } 38\end{array}$ & $62^{\circ} 13^{\prime} 34.3^{\prime \prime S} 58^{\circ} 40^{\prime} 18.2^{\prime \prime} \mathrm{W}$ & $20 \mathrm{~m}$ \\
\hline Orchomenella rotundifrons & MT002Oro012 & LYAPO008-16 & 30516 & Potter Cove, outer cove & $\begin{array}{l}\text { Carlini 14-15 } \\
\text { st } 02\end{array}$ & $62^{\circ} 14^{\prime} 03.2^{\prime \prime} \mathrm{S}, 58^{\circ} 39^{\prime} 17.3^{\prime \prime} \mathrm{W}$ & $30 \mathrm{~m}$ \\
\hline Orchomenella rotundifrons & MT002Oro018 & LYAPO009-16 & 30517 & Potter Cove, outer cove & $\begin{array}{l}\text { Carlini } 14-15 \\
\text { st } 02\end{array}$ & $62^{\circ} 14^{\prime} 03.2^{\prime \prime} \mathrm{S}, 58^{\circ} 39^{\prime} 17.3^{\prime \prime} \mathrm{W}$ & $30 \mathrm{~m}$ \\
\hline Orchomenella rotundifrons & MT002Oro020 & LYAPO010-16 & 30518 & Potter Cove, outer cove & $\begin{array}{l}\text { Carlini 14-15 } \\
\text { st } 02\end{array}$ & $62^{\circ} 14^{\prime} 03.2^{\prime \prime} \mathrm{S}, 58^{\circ} 39^{\prime} 17.3^{\prime \prime} \mathrm{W}$ & $30 \mathrm{~m}$ \\
\hline Orchomenella cf. rotundifrons & MT010Oxx002 & LYAPO011-16 & 30519 & Potter Cove, outer cove & $\begin{array}{l}\text { Carlini 14-15 } \\
\text { st } 10\end{array}$ & $62^{\circ} 14^{\prime} 23.4^{\prime \prime} \mathrm{S}, 58^{\circ} 41^{\prime} 52.5^{\prime \prime} \mathrm{W}$ & $40 \mathrm{~m}$ \\
\hline Orchomenella rotundifrons & MT002Oro013 & LYAPO012-16 & 30520 & Potter Cove, outer cove & $\begin{array}{l}\text { Carlini 14-15 } \\
\text { st } 02\end{array}$ & $62^{\circ} 14^{\prime} 03.2^{\prime \prime} \mathrm{S}, 58^{\circ} 39^{\prime} 17.3^{\prime \prime} \mathrm{W}$ & $30 \mathrm{~m}$ \\
\hline Orchomenella cf. rotundifrons & MT014Oxx048 & LYAPO013-16 & 30521 & Potter Cove, outer cove & $\begin{array}{l}\text { Carlini 14-15 } \\
\text { st } 14\end{array}$ & $62^{\circ} 14^{\prime} 23.4^{\prime \prime} \mathrm{S}, 58^{\circ} 41^{\prime} 52.5^{\prime \prime} \mathrm{W}$ & $40 \mathrm{~m}$ \\
\hline Orchomenella rotundifrons & MT002Oro008 & LYAPO014-16 & 30522 & Potter Cove, outer cove & $\begin{array}{l}\text { Carlini 14-15 } \\
\text { st } 02\end{array}$ & $62^{\circ} 14^{\prime} 03.2^{\prime \prime} \mathrm{S}, 58^{\circ} 39^{\prime} 17.3^{\prime \prime} \mathrm{W}$ & $30 \mathrm{~m}$ \\
\hline Orchomenella cf. rotundifrons & MT010Oxx001 & LYAPO015-16 & 30523 & Potter Cove, outer cove & $\begin{array}{l}\text { Carlini } 14-15 \\
\text { st } 10\end{array}$ & $62^{\circ} 14^{\prime} 23.4^{\prime \prime} \mathrm{S}, 58^{\circ} 41^{\prime} 52.5^{\prime \prime} \mathrm{W}$ & $40 \mathrm{~m}$ \\
\hline Orchomenella cf. rotundifrons & MT010Oxx004 & LYAPO016-16 & 30524 & Potter Cove, outer cove & $\begin{array}{l}\text { Carlini } 14-15 \\
\text { st } 10\end{array}$ & $62^{\circ} 14^{\prime} 23.4^{\prime \prime} \mathrm{S}, 58^{\circ} 41^{\prime} 52.5^{\prime \prime} \mathrm{W}$ & $40 \mathrm{~m}$ \\
\hline Orchomenella rotundifrons & MT002Oro016 & LYAPO017-16 & 30525 & Potter Cove, outer cove & $\begin{array}{l}\text { Carlini 14-15 } \\
\text { st } 02\end{array}$ & $62^{\circ} 14^{\prime} 03.2^{\prime \prime} \mathrm{S}, 58^{\circ} 39^{\prime} 17.3^{\prime \prime} \mathrm{W}$ & $30 \mathrm{~m}$ \\
\hline Orchomenella cf. rotundifrons & MT010Oxx005 & LYAPO018-16 & 30526 & Potter Cove, outer cove & $\begin{array}{l}\text { Carlini 14-15 } \\
\text { st } 10\end{array}$ & $62^{\circ} 14^{\prime} 23.4^{\prime \prime} \mathrm{S}, 58^{\circ} 41^{\prime} 52.5^{\prime \prime} \mathrm{W}$ & $40 \mathrm{~m}$ \\
\hline
\end{tabular}




\begin{tabular}{|c|c|c|c|c|c|c|c|}
\hline Orchomenella rotundifrons & MT002Oro011 & LYAPO019-16 & 30527 & Potter Cove, outer cove & $\begin{array}{l}\text { Carlini 14-15 } \\
\text { st } 02\end{array}$ & $62^{\circ} 14^{\prime} 03.2^{\prime \prime S}, 58^{\circ} 39^{\prime} 17.3^{\prime \prime} \mathrm{W}$ & $30 \mathrm{~m}$ \\
\hline Orchomenella infinita sp.n. & MT009Oul006 & LYAPO020-16 & $\begin{array}{l}30506 \\
\text { holotype }\end{array}$ & Potter Cove, outer cove & $\begin{array}{l}\text { Carlini 14-15 } \\
\text { st } 09\end{array}$ & $62^{\circ} 14^{\prime} 23.4^{\prime \prime} \mathrm{S}, 58^{\circ} 41^{\prime} 52.3^{\prime \prime} \mathrm{W}$ & $39 \mathrm{~m}$ \\
\hline Orchomenella infinita sp.n. & MT002Oul014 & LYAPO021-16 & $\begin{array}{l}30507 \\
\text { paratypes }\end{array}$ & Potter Cove, outer cove & $\begin{array}{l}\text { Carlini 14-15 } \\
\text { st } 02\end{array}$ & $62^{\circ} 14^{\prime} 03.2^{\prime \prime} \mathrm{S}, 58^{\circ} 39^{\prime} 17.3^{\prime \prime} \mathrm{W}$ & $30 \mathrm{~m}$ \\
\hline Orchomenella infinita sp.n. & MT014Oul001 & LYAPO022-16 & $\begin{array}{l}30508 \\
\text { paratypes }\end{array}$ & Potter Cove, outer cove & $\begin{array}{l}\text { Carlini 14-15 } \\
\text { st } 14\end{array}$ & $62^{\circ} 14^{\prime} 23.4^{\prime \prime} \mathrm{S}, 58^{\circ} 41^{\prime} 52.5^{\prime \prime} \mathrm{W}$ & $40 \mathrm{~m}$ \\
\hline Cheirimedon femoratus & MT038Cfe007 & LYAPO023-16 & 30528 & Potter Cove, inner cove & $\begin{array}{l}\text { Carlini 14-15 } \\
\text { st38 }\end{array}$ & $62^{\circ} 13^{\prime} 34.3^{\prime \prime} \mathrm{S} 58^{\circ} 40^{\prime} 18.2^{\prime \prime} \mathrm{W}$ & $20 \mathrm{~m}$ \\
\hline Cheirimedon femoratus & MT013Cfe011 & LYAPO024-16 & 30529 & Potter Cove, outer cove & $\begin{array}{l}\text { Carlini 14-15 } \\
\text { st } 13\end{array}$ & $62^{\circ} 14^{\prime} 23.4^{\prime \prime} \mathrm{S}, 58^{\circ} 41^{\prime} 52.5^{\prime \prime} \mathrm{W}$ & $40 \mathrm{~m}$ \\
\hline Cheirimedon femoratus & MT038Cfe004 & LYAPO025-16 & 30530 & Potter Cove, inner cove & $\begin{array}{l}\text { Carlini 14-15 } \\
\text { st38 }\end{array}$ & $62^{\circ} 13^{\prime} 34.3^{\prime \prime} \mathrm{S} 58^{\circ} 40^{\prime} 18.2^{\prime \prime} \mathrm{W}$ & $20 \mathrm{~m}$ \\
\hline Cheirimedon femoratus & MT013Cfe010 & LYAPO026-16 & 30531 & Potter Cove, outer cove & $\begin{array}{l}\text { Carlini 14-15 } \\
\text { st } 13\end{array}$ & $62^{\circ} 14^{\prime} 23.4^{\prime \prime} \mathrm{S}, 58^{\circ} 41^{\prime} 52.5^{\prime \prime} \mathrm{W}$ & $40 \mathrm{~m}$ \\
\hline Cheirimedon femoratus & MT038Cfe006 & LYAPO027-16 & 30532 & Potter Cove, inner cove & $\begin{array}{l}\text { Carlini 14-15 } \\
\text { st38 }\end{array}$ & $62^{\circ} 13^{\prime} 34.3^{\prime \prime S} 58^{\circ} 40^{\prime} 18.2^{\prime \prime} \mathrm{W}$ & $20 \mathrm{~m}$ \\
\hline Cheirimedon femoratus & MT038Cfe002 & LYAPO028-16 & 30533 & Potter Cove, inner cove & $\begin{array}{l}\text { Carlini 14-15 } \\
\text { st38 }\end{array}$ & $62^{\circ} 13^{\prime} 34.3^{\prime \prime S} 58^{\circ} 40^{\prime} 18.2^{\prime \prime} \mathrm{W}$ & $20 \mathrm{~m}$ \\
\hline Cheirimedon femoratus & MT038Cfe005 & LYAPO029-16 & 30534 & Potter Cove, inner cove & $\begin{array}{l}\text { Carlini 14-15 } \\
\text { st38 }\end{array}$ & $62^{\circ} 13^{\prime} 34.3^{\prime \prime} \mathrm{S} 58^{\circ} 40^{\prime} 18.2^{\prime \prime} \mathrm{W}$ & $20 \mathrm{~m}$ \\
\hline Cheirimedon femoratus & MT038Cfe003 & LYAPO030-16 & 30535 & Potter Cove, inner cove & $\begin{array}{l}\text { Carlini 14-15 } \\
\text { st38 }\end{array}$ & $62^{\circ} 13^{\prime} 34.3^{\prime \prime} \mathrm{S} 58^{\circ} 40^{\prime} 18.2^{\prime \prime} \mathrm{W}$ & $20 \mathrm{~m}$ \\
\hline Cheirimedon femoratus & МT002Cfe009 & LYAPO031-16 & 30536 & Potter Cove, outer cove & $\begin{array}{l}\text { Carlini 14-15 } \\
\text { st } 02\end{array}$ & $62^{\circ} 14^{\prime} 03.2^{\prime \prime} \mathrm{S}, 58^{\circ} 39^{\prime} 17.3^{\prime \prime} \mathrm{W}$ & $30 \mathrm{~m}$ \\
\hline Cheirimedon femoratus & MT013Cfe012 & LYAPO032-16 & 30537 & Potter Cove, outer cove & $\begin{array}{l}\text { Carlini 14-15 } \\
\text { st } 13\end{array}$ & $62^{\circ} 14^{\prime} 23.4^{\prime \prime} \mathrm{S}, 58^{\circ} 41^{\prime} 52.5^{\prime \prime} \mathrm{W}$ & $40 \mathrm{~m}$ \\
\hline Cheirimedon femoratus & MT002Cfe010 & LYAPO033-16 & 30538 & Potter Cove, outer cove & $\begin{array}{l}\text { Carlini 14-15 } \\
\text { st } 02\end{array}$ & $62^{\circ} 14^{\prime} 03.2^{\prime \prime} \mathrm{S}, 58^{\circ} 39^{\prime} 17.3^{\prime \prime} \mathrm{W}$ & $30 \mathrm{~m}$ \\
\hline Cheirimedon femoratus & MT018Cfe002 & LYAPO034-16 & 30539 & Potter Cove, inner cove & $\begin{array}{l}\text { Carlini 14-15 } \\
\text { st } 18\end{array}$ & $62^{\circ} 13^{\prime} 25.3^{\prime \prime} \mathrm{S}, 58^{\circ} 39^{`} 16.3^{\prime \prime} \mathrm{W}$ & $19 \mathrm{~m}$ \\
\hline Cheirimedon femoratus & MT013Cfe009 & LYAPO035-16 & 30540 & Potter Cove, outer cove & $\begin{array}{l}\text { Carlini 14-15 } \\
\text { st } 13\end{array}$ & $62^{\circ} 14^{\prime} 23.4^{\prime \prime} \mathrm{S}, 58^{\circ} 41^{\prime} 52.5^{\prime \prime} \mathrm{W}$ & $40 \mathrm{~m}$ \\
\hline Cheirimedon femoratus & MT013Cfe008 & LYAPO036-16 & 30541 & Potter Cove, outer cove & $\begin{array}{l}\text { Carlini 14-15 } \\
\text { st } 13\end{array}$ & $62^{\circ} 14^{\prime} 23.4^{\prime \prime} \mathrm{S}, 58^{\circ} 41^{\prime} 52.5^{\prime \prime} \mathrm{W}$ & $40 \mathrm{~m}$ \\
\hline Abyssorchomene charcoti & MT002Ach006 & LYAPO037-16 & 30542 & Potter Cove, outer cove & $\begin{array}{l}\text { Carlini 14-15 } \\
\text { st } 02\end{array}$ & $62^{\circ} 14^{\prime} 03.2^{\prime \prime} \mathrm{S}, 58^{\circ} 39^{\prime} 17.3^{\prime \prime} \mathrm{W}$ & $30 \mathrm{~m}$ \\
\hline Pseudorchomene plebs & MT002Pp1001 & LYAPO038-16 & 30543 & Potter Cove, outer cove & $\begin{array}{l}\text { Carlini 14-15 } \\
\text { st } 02\end{array}$ & $62^{\circ} 14^{\prime} 03.2^{\prime \prime} \mathrm{S}, 58^{\circ} 39^{\prime} 17.3^{\prime \prime} \mathrm{W}$ & $30 \mathrm{~m}$ \\
\hline Pseudorchomene rossi & MT033Pro001 & LYAPO039-16 & 30544 & Marian Cove & Carlini 14-15 & $62^{\circ} 12^{\prime} 49.4^{\prime \prime} \mathrm{S} 58^{\circ} 44^{\prime} 55.2^{\prime \prime} \mathrm{W}$ & $25 \mathrm{~m}$ \\
\hline
\end{tabular}




\begin{tabular}{|c|c|c|c|c|c|c|c|}
\hline & & & & & st 33 & & \\
\hline Hippomedon kergueleni & MT013Hke006 & LYAPO040-16 & 30545 & Potter Cove, outer cove & $\begin{array}{l}\text { Carlini 14-15 } \\
\text { st } 13\end{array}$ & $62^{\circ} 14^{\prime} 23.4^{\prime \prime S}, 58^{\circ} 41^{\prime} 52.5^{\prime \prime} \mathrm{W}$ & $40 \mathrm{~m}$ \\
\hline Hippomedon kergueleni & MT013Hke004 & LYAPO041-16 & 30546 & Potter Cove, outer cove & $\begin{array}{l}\text { Carlini 14-15 } \\
\text { st } 13\end{array}$ & $62^{\circ} 14^{\prime} 23.4^{\prime \prime S}, 58^{\circ} 41^{\prime} 52.5^{\prime \prime} \mathrm{W}$ & $40 \mathrm{~m}$ \\
\hline Hippomedon kergueleni & MT009Hke001 & LYAPO042-16 & 30547 & Potter Cove, outer cove & $\begin{array}{l}\text { Carlini 14-15 } \\
\text { st } 09\end{array}$ & $62^{\circ} 14^{\prime} 23.4^{\prime \prime S}, 58^{\circ} 41^{\prime} 52.3^{\prime \prime} \mathrm{W}$ & $39 \mathrm{~m}$ \\
\hline Hippomedon kergueleni & MT013Hke001 & LYAPO043-16 & 30548 & Potter Cove, outer cove & $\begin{array}{l}\text { Carlini 14-15 } \\
\text { st } 13\end{array}$ & $62^{\circ} 14^{\prime} 23.4^{\prime \prime S}, 58^{\circ} 41^{\prime} 52.5^{\prime \prime} \mathrm{W}$ & $40 \mathrm{~m}$ \\
\hline Hippomedon kergueleni & MT009Hke003 & LYAPO044-16 & 30549 & Potter Cove, outer cove & $\begin{array}{l}\text { Carlini 14-15 } \\
\text { st } 09\end{array}$ & $62^{\circ} 14^{\prime} 23.4^{\prime \prime S}, 58^{\circ} 41^{\prime} 52.3^{\prime \prime} \mathrm{W}$ & $39 \mathrm{~m}$ \\
\hline Hippomedon kergueleni & MT013Hke003 & LYAPO045-16 & 30550 & Potter Cove, outer cove & $\begin{array}{l}\text { Carlini 14-15 } \\
\text { st } 13\end{array}$ & $62^{\circ} 14^{\prime} 23.4^{\prime \prime S}, 58^{\circ} 41^{\prime} 52.5^{\prime \prime} \mathrm{W}$ & $40 \mathrm{~m}$ \\
\hline Hippomedon kergueleni & MT013Hke005 & LYAPO046-16 & 30551 & Potter Cove, outer cove & $\begin{array}{l}\text { Carlini 14-15 } \\
\text { st } 13\end{array}$ & $62^{\circ} 14^{\prime} 23.4^{\prime \prime S}, 58^{\circ} 41^{\prime} 52.5^{\prime \prime} \mathrm{W}$ & $40 \mathrm{~m}$ \\
\hline Hippomedon kergueleni & MT009Hke002 & LYAPO047-16 & 30552 & Potter Cove, outer cove & $\begin{array}{l}\text { Carlini 14-15 } \\
\text { st } 09\end{array}$ & $62^{\circ} 14^{\prime} 23.4^{\prime \prime S}, 58^{\circ} 41^{\prime} 52.3^{\prime \prime} \mathrm{W}$ & $39 \mathrm{~m}$ \\
\hline Hippomedon kergueleni & MT013Hke007 & LYAPO048-16 & 30553 & Potter Cove, outer cove & $\begin{array}{l}\text { Carlini 14-15 } \\
\text { st } 13\end{array}$ & $62^{\circ} 14^{\prime} 23.4^{\prime \prime S}, 58^{\circ} 41^{\prime} 52.5^{\prime \prime} \mathrm{W}$ & $40 \mathrm{~m}$ \\
\hline Hippomedon kergueleni & MT009Hke005 & LYAPO049-16 & 30554 & Potter Cove, outer cove & $\begin{array}{l}\text { Carlini 14-15 } \\
\text { st } 09\end{array}$ & $62^{\circ} 14^{\prime} 23.4^{\prime \prime S}, 58^{\circ} 41^{\prime} 52.3^{\prime \prime} \mathrm{W}$ & $39 \mathrm{~m}$ \\
\hline Hippomedon kergueleni & MT002Hke004 & LYAPO050-16 & 30555 & Potter Cove, outer cove & $\begin{array}{l}\text { Carlini } 14-15 \\
\text { st } 02\end{array}$ & $62^{\circ} 14^{\prime} 03.2^{\prime \prime S}, 58^{\circ} 39^{\prime} 17.3^{\prime \prime} \mathrm{W}$ & $30 \mathrm{~m}$ \\
\hline Hippomedon kergueleni & MT002Hke005 & LYAPO051-16 & 30556 & Potter Cove, outer cove & $\begin{array}{l}\text { Carlini } 14-15 \\
\text { st } 02\end{array}$ & $62^{\circ} 14^{\prime} 03.2^{\prime \prime S}, 58^{\circ} 39^{\prime} 17.3^{\prime \prime} \mathrm{W}$ & $30 \mathrm{~m}$ \\
\hline Hippomedon kergueleni & MT011Hke001 & LYAPO052-16 & 30557 & Potter Cove, outer cove & $\begin{array}{l}\text { Carlini 14-15 } \\
\text { st } 11\end{array}$ & $62^{\circ} 14^{\prime} 23.4^{\prime \prime S}, 58^{\circ} 41^{\prime} 52.5^{\prime \prime} \mathrm{W}$ & $40 \mathrm{~m}$ \\
\hline Hippomedon kergueleni & MT002Hke021 & LYAPO053-16 & 30558 & Potter Cove, outer cove & $\begin{array}{l}\text { Carlini 14-15 } \\
\text { st } 02\end{array}$ & $62^{\circ} 14^{\prime} 03.2^{\prime \prime S}, 58^{\circ} 39^{\prime} 17.3^{\prime \prime} \mathrm{W}$ & $30 \mathrm{~m}$ \\
\hline Hippomedon kergueleni & MT011Hke003 & LYAPO054-16 & 30559 & Potter Cove, outer cove & $\begin{array}{l}\text { Carlini 14-15 } \\
\text { st } 11\end{array}$ & $62^{\circ} 14^{\prime} 23.4^{\prime \prime S}, 58^{\circ} 41^{\prime} 52.5^{\prime \prime} \mathrm{W}$ & $40 \mathrm{~m}$ \\
\hline Hippomedon kergueleni & MT011Hke006 & LYAPO055-16 & 30560 & Potter Cove, outer cove & $\begin{array}{l}\text { Carlini 14-15 } \\
\text { st } 11\end{array}$ & $62^{\circ} 14^{\prime} 23.4^{\prime \prime S}, 58^{\circ} 41^{\prime} 52.5^{\prime \prime} \mathrm{W}$ & $40 \mathrm{~m}$ \\
\hline Hippomedon kergueleni & MT011Hke002 & LYAPO056-16 & 30561 & Potter Cove, outer cove & $\begin{array}{l}\text { Carlini 14-15 } \\
\text { st } 11\end{array}$ & $62^{\circ} 14^{\prime} 23.4^{\prime \prime S}, 58^{\circ} 41^{\prime} 52.5^{\prime \prime} \mathrm{W}$ & $40 \mathrm{~m}$ \\
\hline Hippomedon kergueleni & MT011Hke005 & LYAPO057-16 & 30562 & Potter Cove, outer cove & $\begin{array}{l}\text { Carlini 14-15 } \\
\text { st } 11\end{array}$ & $62^{\circ} 14^{\prime} 23.4^{\prime \prime S}, 58^{\circ} 41^{\prime} 52.5^{\prime \prime} \mathrm{W}$ & $40 \mathrm{~m}$ \\
\hline Hippomedon kergueleni & MT011Hke004 & LYAPO058-16 & 30563 & Potter Cove, outer cove & $\begin{array}{l}\text { Carlini 14-15 } \\
\text { st } 11\end{array}$ & $62^{\circ} 14^{\prime} 23.4^{\prime \prime} \mathrm{S}, 58^{\circ} 41^{\prime} 52.5^{\prime \prime} \mathrm{W}$ & $40 \mathrm{~m}$ \\
\hline Waldeckia obesa cluster 'A' & MT011Wob010 & LYAPO059-16 & 30564 & Potter Cove, outer cove & $\begin{array}{l}\text { Carlini 14-15 } \\
\text { st } 11\end{array}$ & $62^{\circ} 14^{\prime} 23.4^{\prime \prime S}, 58^{\circ} 41^{\prime} 52.5^{\prime \prime} \mathrm{W}$ & $40 \mathrm{~m}$ \\
\hline
\end{tabular}




\begin{tabular}{|c|c|c|c|c|c|c|c|}
\hline Waldeckia obesa cluster 'A' & MT013Wob014 & LYAPO060-16 & 30565 & Potter Cove, outer cove & $\begin{array}{l}\text { Carlini 14-15 } \\
\text { st } 13\end{array}$ & $62^{\circ} 14^{\prime} 23.4^{\prime \prime S}, 58^{\circ} 41^{\prime} 52.5^{\prime \prime} \mathrm{W}$ & $40 \mathrm{~m}$ \\
\hline Waldeckia obesa cluster 'A' & MT011Wob008 & LYAPO061-16 & 30566 & Potter Cove, outer cove & $\begin{array}{l}\text { Carlini 14-15 } \\
\text { st } 11\end{array}$ & $62^{\circ} 14^{\prime} 23.4^{\prime \prime S}, 58^{\circ} 41^{\prime} 52.5^{\prime \prime} \mathrm{W}$ & $40 \mathrm{~m}$ \\
\hline Waldeckia obesa cluster 'A' & MT013Wob016 & LYAPO062-16 & 30567 & Potter Cove, outer cove & $\begin{array}{l}\text { Carlini 14-15 } \\
\text { st } 13\end{array}$ & $62^{\circ} 14^{\prime} 23.4^{\prime \prime S}, 58^{\circ} 41^{\prime} 52.5^{\prime \prime} \mathrm{W}$ & $40 \mathrm{~m}$ \\
\hline Waldeckia obesa cluster 'A' & MT011Wob009 & LYAPO063-16 & 30568 & Potter Cove, outer cove & $\begin{array}{l}\text { Carlini 14-15 } \\
\text { st } 11\end{array}$ & $62^{\circ} 14^{\prime} 23.4^{\prime \prime S}, 58^{\circ} 41^{\prime} 52.5^{\prime \prime} \mathrm{W}$ & $40 \mathrm{~m}$ \\
\hline Waldeckia obesa cluster 'A' & MT013Wob013 & LYAPO064-16 & 30569 & Potter Cove, outer cove & $\begin{array}{l}\text { Carlini 14-15 } \\
\text { st } 13\end{array}$ & $62^{\circ} 14^{\prime} 23.4^{\prime \prime S}, 58^{\circ} 41^{\prime} 52.5^{\prime \prime} \mathrm{W}$ & $40 \mathrm{~m}$ \\
\hline Waldeckia obesa cluster 'A' & MT011Wob007 & LYAPO065-16 & 30570 & Potter Cove, outer cove & $\begin{array}{l}\text { Carlini 14-15 } \\
\text { st } 11\end{array}$ & $62^{\circ} 14^{\prime} 23.4^{\prime \prime} \mathrm{S}, 58^{\circ} 41^{\prime} 52.5^{\prime \prime} \mathrm{W}$ & $40 \mathrm{~m}$ \\
\hline Waldeckia obesa cluster 'A' & MT009Wob008 & LYAPO066-16 & 30571 & Potter Cove, outer cove & $\begin{array}{l}\text { Carlini 14-15 } \\
\text { st } 09\end{array}$ & $62^{\circ} 14^{\prime} 23.4^{\prime \prime} \mathrm{S}, 58^{\circ} 41^{\prime} 52.3^{\prime \prime} \mathrm{W}$ & $39 \mathrm{~m}$ \\
\hline Waldeckia obesa cluster 'A' & MT014Wob135 & LYAPO067-16 & 30572 & Potter Cove, outer cove & $\begin{array}{l}\text { Carlini 14-15 } \\
\text { st } 14\end{array}$ & $62^{\circ} 14^{\prime} 23.4^{\prime \prime} \mathrm{S}, 58^{\circ} 41^{\prime} 52.5^{\prime \prime} \mathrm{W}$ & $40 \mathrm{~m}$ \\
\hline Waldeckia obesa cluster 'A' & MT014Wob134 & LYAPO068-16 & 30573 & Potter Cove, outer cove & $\begin{array}{l}\text { Carlini 14-15 } \\
\text { st } 14\end{array}$ & $62^{\circ} 14^{\prime} 23.4^{\prime \prime S}, 58^{\circ} 41^{\prime} 52.5^{\prime \prime} \mathrm{W}$ & $40 \mathrm{~m}$ \\
\hline Waldeckia obesa cluster 'A' & MT009Wob007 & LYAPO069-16 & 30574 & Potter Cove, outer cove & $\begin{array}{l}\text { Carlini 14-15 } \\
\text { st } 09\end{array}$ & $62^{\circ} 14^{\prime} 23.4^{\prime \prime S}, 58^{\circ} 41^{\prime} 52.3^{\prime \prime} \mathrm{W}$ & $39 \mathrm{~m}$ \\
\hline Waldeckia obesa cluster 'A' & Wo-1412103 & LYAPO070-17 & - & Antarctic Peninsula & $\begin{array}{l}\text { ANT-XXIII-8 } \\
689-5\end{array}$ & $62^{\circ} 27^{\prime \prime S}, 55^{\circ} 25^{\prime \prime} \mathrm{W}$ & $211 \mathrm{~m}$ \\
\hline Waldeckia obesa cluster 'A' & Wo-2311094 & LYAPO071-17 & - & Haakon VII Sea & $\begin{array}{l}\text { BELARE } \\
\text { AT }\end{array}$ & $70^{\circ} \mathrm{S}, 5^{\circ} \mathrm{E}$ & $130 \mathrm{~m}$ \\
\hline Waldeckia obesa cluster 'B' & Wo-18051013 & LYAPO072-17 & - & Terre Adélie Coast & $\begin{array}{l}\text { CEAMARC } \\
\text { ST13A EV } 465\end{array}$ & $66^{\circ} 08^{\prime \prime S}, 140^{\circ} 38^{\prime \prime} \mathrm{E}$ & $213 \mathrm{~m}$ \\
\hline Waldeckia obesa cluster 'B' & Wo-02121013 & LYAPO073-17 & - & George V Coast & $\begin{array}{l}\text { CEAMARC } \\
\text { St47EV201(1243) }\end{array}$ & $67^{\circ} 04^{\prime \prime S}, 144^{\circ} 39^{\prime \prime} \mathrm{E}$ & $194 \mathrm{~m}$ \\
\hline Waldeckia obesa cluster 'B' & $\begin{array}{l}\text { Wo-23110910- } \\
\text { AMPBE019-10 }\end{array}$ & AMPBE019-10 & - & $\begin{array}{l}\text { Haakon VII Sea Crown } \\
\text { Bay }\end{array}$ & BELARE AT & $70^{\circ} \mathrm{S}, 23^{\circ} \mathrm{E}$ & 230 \\
\hline Waldeckia obesa cluster 'B' & Wo-2904104 & LYAPO074-17 & - & Amundsen Sea & $\begin{array}{l}\text { JR179 BIOPEARL II } \\
\text { KL-06-0769 }\end{array}$ & n.a. & n.a. \\
\hline Waldeckia obesa cluster 'B' & $\begin{array}{l}\text { Wo-06041013- } \\
\text { AMPBE044-10 }\end{array}$ & AMPBE044-10 & - & Eastern Weddell Sea & $\begin{array}{l}\text { ANT XXVII-3 } \\
275-3 \text { AGT }\end{array}$ & $70^{\circ} 56^{\prime \prime} \mathrm{S}, 10^{\circ} 29^{\prime \prime} \mathrm{W}$ & $226 \mathrm{~m}$ \\
\hline Waldeckia obesa cluster 'B' & $\begin{array}{l}\text { Wo-ANT27 } \\
3-118\end{array}$ & LYAPO075-17 & - & $\begin{array}{l}\text { Haakon VII Sea Crown } \\
\text { Bay }\end{array}$ & $\begin{array}{l}\text { BELARE } \\
\text { AT }\end{array}$ & $70^{\circ} \mathrm{S}, 5^{\circ} \mathrm{E}$ & $130 \mathrm{~m}$ \\
\hline Waldeckia obesa cluster 'B' & Wo-1412106 & LYAPO076-17 & - & Eastern Weddell Sea & $\begin{array}{l}\text { ANT XXIV-2 } \\
48 \text { AGT }\end{array}$ & $70^{\circ} 24^{\prime \prime} \mathrm{S}, 08^{\circ} 19^{\prime \prime} \mathrm{W}$ & $602 \mathrm{~m}$ \\
\hline Waldeckia obesa cluster 'B' & Wo-1412108 & LYAPO077-17 & - & Eastern Weddell Sea & $\begin{array}{l}\text { ANT XXIV-2 } \\
48 \text { AGT }\end{array}$ & $70^{\circ} 24^{\prime \prime} \mathrm{S}, 08^{\circ} 19^{\prime \prime} \mathrm{W}$ & $602 \mathrm{~m}$ \\
\hline
\end{tabular}


Table 3 K2P genetic distances within and between species, Ach: Abyssorchomene charcoti, Cfe: Cheirimedon femoratus, Hke: Hippomedon kergueleni, Oul: Orchomenella infinita sp. n. Oro: Orchomenella rotundifrons, Ppl: Pseudorchomene plebs, Pro: Pseudorchomene rossi, Wob_A: Waldeckia obesa cluster 'A', Wob_B: Waldeckia obesa cluster 'B', n.a.: not applicable

$\begin{array}{lccccccccc} & \text { Ach } & \text { Cfe } & \text { Oin } & \text { Oro } & \text { Hke } & \text { Ppl } & \text { Pro } & \text { Wob_A } & \text { Wob_B } \\ \text { Ach } & \text { n.a. } & & & & & & & & \\ \text { Cfe } & 10.3-10.7 & 0.0-0.7 & & & & & & & \\ \text { Oin } & 17.4-17.5 & 17.4-17.7 & 0.00 & & & & & & \\ \text { Oro } & 10.2-11.3 & 12.9-13.8 & 19.5-20.3 & 0.0-1.5 & & & & & \\ \text { Hke } & 29.8-30.7 & 29.4-30.7 & 36.1-37.0 & 30.5-32.5 & 0.0-0.7 & & & \\ \text { Ppl } & 15.5 & 14.2-14.7 & 18.8 & 17.3-18.1 & 30.8-32.2 & \text { n.a. } & & \\ \text { Pro } & 15.8 & 15.5-16.2 & 16.4-16.5 & 15.7-16.6 & 30.6-32.2 & 12.0 & \text { n.a. } & & \\ \text { Wob_A } & 29.6-32.5 & 31.7-35.6 & 34.0-37.0 & 30.2-33.7 & 27.6-30.4 & 34.2-37.3 & 33.6-36.2 & 0.0-2.8 & \\ \text { Wob_B } & 33.3-35.4 & 34.4-37.2 & 37.3-40.1 & 34.1-37.8 & 24.8-28.2 & 37.3-38.9 & 34.8-37.4 & 15.0-18.1 & 0.0-1.7\end{array}$


Table 4 Relative and total abundances of lysianassoid amphipod species found in Potter Cove and Marian Cove

\begin{tabular}{|c|c|c|c|c|c|c|c|c|}
\hline & \multicolumn{2}{|l|}{ Potter Cove } & \multicolumn{2}{|l|}{ Outer cove } & \multicolumn{2}{|l|}{ Inner cove } & \multicolumn{2}{|l|}{ Marian Cove } \\
\hline & No of specimens & $\%$ & No of specimens & $\%$ & No of specimens & $\%$ & No of specimens & $\%$ \\
\hline Cheirimedon femoratus & 33,440 & 79.81 & 17,466 & 67.61 & 15,974 & 99.44 & 260 & 12.75 \\
\hline Hippomedon kergueleni & 5808 & 13.86 & 5747 & 22.25 & 61 & 0.38 & 3 & 1.47 \\
\hline Orchomenella rotundifrons & 2110 & 5.04 & 2086 & 8.07 & 24 & 0.15 & - & - \\
\hline Orchomenella infinita sp. $\mathrm{n}$. & 6 & $<0.01$ & 5 & 0.02 & 1 & 0.006 & - & - \\
\hline Pseudorchomene coatsi & 3 & $<0.01$ & - & - & 3 & 0.02 & - & - \\
\hline Pseudorchomene plebs & 2 & $<0.01$ & 1 & $<0.01$ & 1 & 0.006 & - & - \\
\hline Abyssorchomene charcoti & 2 & $<0.01$ & 2 & $<0.01$ & 0 & - & - & - \\
\hline Pseudorchomene rossi & 3 & $<0.01$ & - & - & 1 & 0.006 & 2 & 0.1 \\
\hline Orchomenella pinguides & 1 & $<0.01$ & 1 & $<0.01$ & 0 & - & - & - \\
\hline Total & $4 \mathbf{4 1 , 8 9 8}$ & & $2 \mathbf{2 5 , 8 3 2}$ & & $10 \mathbf{1 6 , 0 6 4}$ & & 2039 & \\
\hline
\end{tabular}


Supplement material 1 Numbers of lysianassoid amphipod specimens per species and station in Potter Cove and Marian Cove. Yellow: Outer Potter Cove; Blue: Inner Potter Cove; Grey: Marian Cove

\begin{tabular}{|c|c|c|c|c|c|c|c|c|c|c|c|}
\hline Station ID & $\begin{array}{l}\text { Cheirimedon } \\
\text { femoratus }\end{array}$ & $\begin{array}{l}\text { Waldeckia } \\
\text { obesa }\end{array}$ & $\begin{array}{l}\text { Hippomedon } \\
\text { kergueleni }\end{array}$ & $\begin{array}{l}\text { Orchomenella } \\
\text { rotundifrons }\end{array}$ & $\begin{array}{l}\text { Orchomenella } \\
\text { infinita sp.n }\end{array}$ & $\begin{array}{l}\text { Abyssorchomene } \\
\text { charcoti }\end{array}$ & $\begin{array}{l}\text { Pseudorchomene } \\
\text { rossi }\end{array}$ & $\begin{array}{l}\text { Pseudorchomene } \\
\text { plebs }\end{array}$ & $\begin{array}{l}\text { Pseudorchomene } \\
\text { coatsi }\end{array}$ & $\begin{array}{l}\text { Orchomenella } \\
\text { pinguides }\end{array}$ & \\
\hline 02 & 793 & 0 & 658 & 1589 & 2 & 2 & 0 & 1 & 0 & 0 & \\
\hline 07 & 8 & 0 & 0 & 0 & 0 & 0 & 0 & 0 & 0 & 0 & \\
\hline 09 & 404 & 196 & 275 & 2 & 1 & 0 & 0 & 0 & 0 & 0 & \\
\hline 10 & 1664 & 2 & 2 & 23 & 0 & 0 & 0 & 0 & 0 & 0 & \\
\hline 11 & 360 & 83 & 30 & 20 & 0 & 0 & 0 & 0 & 0 & 0 & \\
\hline 12 & 3 & 7 & 29 & 3 & 0 & 0 & 0 & 0 & 0 & 0 & \\
\hline 13 & 1082 & 123 & 55 & 34 & 0 & 0 & 0 & 0 & 0 & 0 & \\
\hline 16 & 536 & 0 & 6 & 1 & 0 & 0 & 0 & 0 & 0 & 0 & \\
\hline 17 & 156 & 0 & 4 & 0 & 0 & 0 & 0 & 0 & 0 & 0 & \\
\hline 18 & 227 & 0 & 0 & 0 & 0 & 0 & 0 & 0 & 0 & 0 & \\
\hline 19 & 2667 & 2 & 978 & 195 & 0 & 0 & 0 & 0 & 0 & 0 & \\
\hline 27 & 462 & 0 & 2790 & 63 & 0 & 0 & 0 & 0 & 0 & 0 & \\
\hline 28 & 2004 & 0 & 346 & 29 & 0 & 0 & 0 & 0 & 0 & 0 & \\
\hline 31 & 11 & 605 & 2 & 0 & 0 & 0 & 0 & 0 & 0 & 0 & \\
\hline 32 & 78 & 856 & 1 & 0 & 0 & 0 & 0 & 0 & 0 & 0 & \\
\hline 35 & 148 & 0 & 0 & 0 & 0 & 0 & 0 & 0 & 0 & 0 & \\
\hline 37 & 6 & 0 & 6 & 0 & 0 & 0 & 0 & 0 & 0 & 0 & \\
\hline 38 & 2403 & 0 & 3 & 12 & 0 & 0 & 0 & 0 & 0 & 0 & \\
\hline 41 & 11,922 & 0 & 0 & 0 & 0 & 0 & 0 & 0 & 0 & 0 & \\
\hline 42 & 548 & 0 & 20 & 8 & 0 & 0 & 1 & 1 & 0 & 0 & \\
\hline 43 & 168 & 1 & 22 & 3 & 1 & 0 & 0 & 0 & 3 & 0 & \\
\hline 45 & 7134 & 0 & 45 & 12 & 0 & 0 & 0 & 0 & 0 & 1 & \\
\hline Total & 33,700 & 2,299 & 5,811 & 2,110 & 6 & 2 & 3 & 2 & 3 & 1 & $\underline{\mathbf{4 3 , 9 3 7}}$ \\
\hline
\end{tabular}

